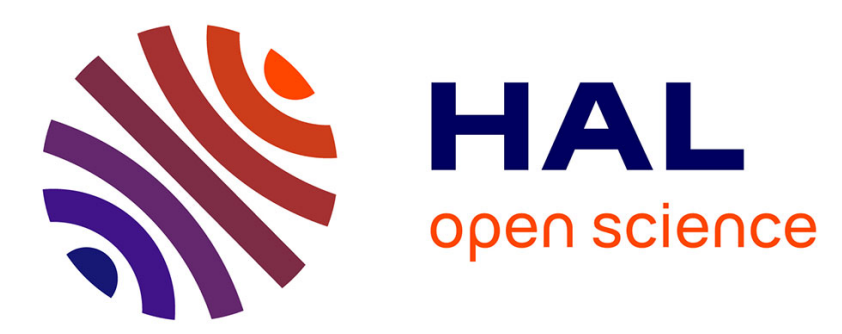

\title{
Neuroanatomical pathways underlying the effects of hypothalamo-hypophysial-adrenal hormones on exploratory activity
}

Robert Lalonde, Catherine Strazielle

\section{- To cite this version:}

Robert Lalonde, Catherine Strazielle. Neuroanatomical pathways underlying the effects of hypothalamo-hypophysial-adrenal hormones on exploratory activity. Reviews in the Neurosciences, 2017, 28 (6), pp.617-648. 10.1515/revneuro-2016-0075 . hal-03219980

\section{HAL Id: hal-03219980 \\ https://hal.univ-lorraine.fr/hal-03219980}

Submitted on 7 May 2021

HAL is a multi-disciplinary open access archive for the deposit and dissemination of scientific research documents, whether they are published or not. The documents may come from teaching and research institutions in France or abroad, or from public or private research centers.
L'archive ouverte pluridisciplinaire HAL, est destinée au dépôt et à la diffusion de documents scientifiques de niveau recherche, publiés ou non, émanant des établissements d'enseignement et de recherche français ou étrangers, des laboratoires publics ou privés. 
Rev Neurosci

Neuroanatomical pathways underlying the effects of hypothalamo-hypophysialadrenal hormones on exploratory activity

Robert Lalonde ${ }^{1}$ and Catherine Strazielle ${ }^{2}$

${ }^{1}$ Université de Rouen, Dépt Psychologie, Laboratoire ICONES EA 4699, 76821 Mont-Saint-Aignan Cedex France, TEL +33 02351461 08, FAX +33 02351463 49, Email: robert.lalonde@univ-rouen.fr

${ }^{2}$ Université de Lorraine, Laboratoire "Stress, Immunité, Pathogènes" EA 7300 and Service de Microscopie Electronique, Faculté de Médecine, 9 avenue de la Forêt de Haye, CHRU de Nancy, 54500 Vandoeuvre-les-Nancy, France 


\section{ABSTRACT}

When injected via the intracerebroventricular route, corticosterone-releasing hormone $(\mathrm{CRH})$ reduced exploration in the elevated plus-maze, the center region of the open-field, and the large chamber in the defensive withdrawal test. The anxiogenic action of $\mathrm{CRH}$ in the elevated plus-maze also occurred when infused in basolateral amygdala, ventral hippocampus, lateral septum, bed nucleus of the stria terminalis, nucleus accumbens, periaqueductal grey, and medial frontal cortex. The anxiogenic action of $\mathrm{CRH}$ in the defensive withdrawal test was reproduced when injected in the locus coeruleus, while the amygdala, hippocampus, lateral septum, nucleus accumbens, and lateral globus pallidus contribute to center zone exploration in the open-field. In addition to elevated plus-maze and open-field tests, the amygdala appears as a target region for $\mathrm{CRH}$-mediated anxiety in the elevated $\mathrm{T}$ maze. Thus, the amygdala is the principal brain region identified with these three tests and further research must identify the neural circuits underlying this form of anxiety.

\section{KEY WORDS}

Corticosterone-releasing hormone; Adrenocorticotropin; Open-field; Hole-Board; Multicompartment Chamber; Elevated Plus-Maze; Elevated T-Maze; Emergence Test; Depensive Withdrawal Test; Light-Dark Box 


\section{HPA axis and behavior}

Figure 1 provides an overall view of anatomical regions subserving the stress response. The paraventricular hypothalamus secretes into hypophysial portal vessels corticosterone-releasing hormone $(\mathrm{CRH})$, a 41 amino acid neuropeptide that promotes the release from the pituitary gland of adrenocorticotropin $(A C T H)$, which in turn releases glucorticoids from the adrenal gland (Selye, 1976; Vale et al., 1981). Once in the general circulation, glucocorticoids exert feedback inhibition on hypothalamic $\mathrm{CRH}$ and hypophysial ACTH (Canny et al., 1989; Keller-Wood and Dallman, 1984). CRH may also exert positive feedback control on paraventricular $\mathrm{CRH}$ neurons via $\mathrm{CRH}$ receptor-1 (CRHR1) (Mansi et al., 1996). In addition to the paraventricular hypothalamus, $\mathrm{CRH}$-containing neurons are found in the bed nucleus of the stria terminalis (Merchenthaler et al., 1982; Phelix and Paull, 1990), which projects to the paraventricular hypothalamus (Champagne et al., 1998) and the dorsal vagal complex (Gray and Magnuson, 1987). CRH-containing neurons in the bed nucleus of the stria terminalis and central amygdala communicate with a wide range of forebrain structures (Gray, 1993; Heinrichs and Koob, 2004; Swanson et al., 1983).

\section{1 $\mathrm{CRH}$, glucocorticoid, and mineralocorticoid receptors}

$\mathrm{CRH}$ binds to two receptors: CRHR1 and CRHR2 (Hashimoto et al., 2001; Hauger et al., 2006; Keenan et al., 2016; Orozco-Cabal et al., 2006; Steckler and Holsboer, 1999; Vaughan et al., 1995), preferentially to CRHR1, while urocortin-1 binds preferentially to CRHR2 (Bittencourt et al., 1999; Vaughan et al., 1995). In one preparation rich in $\mathrm{CRHR} 2, \mathrm{CRH}$ was 30 -fold less potent than urocortin-1, urotensin, and sauvagine (Donaldson et al., 1996) and 100-fold less potent than urocortin-2 (Reyes et al., 2001). Urocortin-3 is another selective CRHR2 agonist (Venihaki et al., 
2004) and its immunoreactive fibers project to areas where CRHR2 is highly expressed (Li et al., 2002).

In rodent brain, CRHR1 expression is highest in pituitary gland, neocortex, medial septum, basolateral amygdala, brainstem cholinergic nuclei, and cerebellum, CRHR2 highest in paraventricular hypothalamus, lateral septum, bed nucleus of the stria terminalis, cortical and medial amygdala as well as peripheral tissues, and a mixed population of both receptors prevalent in hippocampus and periaqueductal grey (Chalmers et al., 1995; Potter et al., 1994; Steckler and Holsboer, 1999; Van Pett et al., 2000). CRHR1 is particularly dense on pyramidal cells throughout neoand paleo-cortex (Chen et al., 2000), where a ventral noradrenergic a1-adrenergic signal may inhibit behavioral activity via inhibition of excitatory glutamatergic neurotransmission (Forray and Gysling, 2004; Koob and Heinrichs, 1999). Urocortin1 expression is highest in lateral hypothalamus, supraoptic nucleus, lateral superior olive, and Edinger-Westphal nucleus, areas not containing $\mathrm{CRH}$ mRNA (Donaldson et al., 1996; Vaughan et al., 1995). Prominent projections from the Edinger-Westphal region to lateral septum and dorsal raphe (Bittencourt et al., 1999) may be responsible for its effects on exploratory activity. On the basis of pharmacological and genetic sources, activation of the hypothalamo-hypophyseal-adrenal (HPA) axis is primarily CRHR1-mediated (Steckler and Holsboer, 1999).

Corticosterone receptors share anatomic sites with the mineralocorticoid receptor agonist, aldosterone, the latter being maximal in hippocampus, amygdala, and septum, distinct from dexamethasone binding to the glucocorticoid receptor, lower in density in the limbic system but maximal at hypothalamic and pituitary sites (McEwen et al., 1979; Warembourg, 1975). Both glucorticoid and mineralocorticoid agonists act on the mineralocorticoid receptor (Gomez-Sanchez and Gomez- 
Sanchez, 2014), whereas dexamethasone is a much more selective agonist at the glucocorticoid site (Spencer et al., 1991). Glucocorticoid receptor mapping indicates high immunoreactivity in paraventricular, anterior periventricular, and ventral mediobasal hypothalamus as well as CA1-CA2 subregions of the hippocampal formation, medium to high immunoreactivity throughout neocortex, and medium immunoreactivity in thalamic nuclei and central amygdala (Fuxe et al., 1985; Morimoto et al., 1996). There is also medium to high immunoreactivity of this receptor on monoaminergic neurons containing dopamine, noradrenaline, and 5hydroxytryptamine (5HT) (Härfstrand et al., 1986). Glucocorticoid receptor expression is also abundant in the nucleus of the solitary tract (Herman, 1993). In addition to neurons, the glucocorticoid receptor is prominent on glial cells (Vielkind et al., 1990).

Mineralocorticoid receptors are mostly occupied under basal corticosterone levels while glucocorticoid receptors are mostly occupied under stressful conditions or circadian peaks (De Kloet, 1991). Indeed, levels of corticosterone, the main adrenal hormone in rodents commonly measured by fluorescence (Zenker and Bernstein, 1958) or radioimmunuassay (Etches, 1976; Murphy, 1967), fluctuate according to daily rythms (Beuving and Vonder, 1977). The mixed population of glucocorticoid and mineralocorticoid receptors present in the hippocampus differs on electrophysiological grounds. In the CA1 subregion of the hippocampal slice, population spike-long term potentiation (PS-LTP) amplitudes were greater than normal only at low corticosterone concentrations and high calcium medium (Rey et al., 1994). PS-LTP amplitudes increased similarly after applying the mineralocorticoid receptor agonist, aldosterone. At high corticosterone concentrations, PS-LTP amplitudes decreased in either high or low calcium medium, an effect reversed by coapplication with a glucocorticoid receptor antagonist, RU486 (also known as 
RU38486 or mifepristone, Allen et al., 1988). Still on hippocampal slices, mifepristone decreased population spike amplitudes in mice (Rey et al., 1989) and adrenalectomized rats, an effect counteracted by corticosterone, in turn suppressed by mifepristone (Joëls and de Kloet, 1989). The lower amplitudes after hyperpolarization in adrenalectomized rats were enhanced in aged relative to young rats (Kerr et al., 1989). Unlike most types of habituation, habituation of the HPA axis is paradoxically stronger and quicker after exposure to more severe or longer-lasting stimuli (Rabasa et al., 2015).

\subsection{Glucocorticoid effects on neurotransmitters}

Glucocorticoids affect neurotransmitters involved in exploratory activity or anxiety, including gamma-amino butyric acid (GABA) and monoamines such as dopamine, noradrenaline, and $5 \mathrm{HT}$ originating in brainstem and projecting widely to the limbic system and neocortex (McEwen et al., 1979; Moore and Bloom, 1979). In particular, corticosterone blocked GABA reuptake in the hippocampus (Miller et al., 1978) and facilitated $5 \mathrm{HT}$ reuptake and release in the hypothalamus (Cardinali and Gomez, 1977; Vermes et al., 1976). In several brain regions, CRH increased concentrations of dihydroxyphenylacetic acid (DOPAC), the main dopamine catabolite, and 3-methoxy,4-hydroxyphenylethyleneglycol (MHPG), the main noradrenaline catabolite (Dunn and Berridge, 1987). But in other brain regions, CRH had no effect on dopamine, noradrenaline, and 5HT concentrations. In the hypothalamus, intracerebroventricular (icv)-infused $\mathrm{CRH}$ increased levels of dopamine, noradrenaline, and the major 5HT metabolite, 5-hydroxy-indole-acetic acid (5HIAA) (Song et al., 1995). Likewise, $\mathrm{CRH}$ injected in the ventral tegmental area decreased dopamine metabolism in the prefrontal cortex as measured by homovanillic acid and 3,4-dihydroxyphenylacetic acid concentrations (Kalivas et al., 
1987). Effects on noradrenaline may include the periphery, since dexamethasone and another synthetic glucocorticoid, RU28362, increased beta-adrenergic binding in arterial smooth muscle cells (Jazayeri and Meyer, 1988).

\subsection{Glucocorticoid effects on inflammation}

In addition to direct actions on neurotransmitter function, HPA peptides may affect behavior via inflammatory-related processes. In contrast to the antiinflammatory action of glucocorticoids (Sapolsky et al., 2000), CRH possesses proinflammatory properties (Karalis et al., 1991), as do the glucocorticoid receptor antagonist, mifepristone (Laue et al., 1988). In particular, glucocorticoids are involved in inflammation-mediated arthritis. Indeed, arthritic-susceptible Lewis rats were impaired in corticotropin and corticosterone responses to group A streptococcal cell wall pepotidoglycan polysaccharide, whereas arthritic-free Fischer rats were not (Sternberg et al., 1989).

\subsection{Molecular pathways of $\mathrm{CRH}$ effects}

Several molecular pathways have been identified regarding $\mathrm{CRH}$-mediated effects (Hauger et al., 2006, 2009). In particular, Epac-dependent CRHR1 signaling via the extracellular signal-regulated kinase/mitogen-activated protein kinase (ERKMAPK) pathway potentiates brain-derived neurotrophic factor (BDNF)-stimulated tropomyosin receptor kinase $B$ (TrkB) signaling. CRHR1 may mediate active defensive responses triggered by escapable stressors and CRHR2 anxiety-like responses induced by inescapable, uncontrollable stressors.

\subsection{Behavioral tests}

Although several reviews have appeared since the 1980s concerning HPA hormones and behavior (Dunn and Berridge, 1990; Koob and Bloom, 1985; Koob and Heinrichs, 1999; Koob et al., 1993; Reul and Holsboer, 2002; Steckler and 
Holsboer, 1999; Sterner and Kalynchuk, 2010; Tovote et al., 2015), none provides a global picture on the neuroanatomical basis of exploratory activity in open-field, holeboard, elevated plus-maze, elevated T-maze, defensive withdrawal, and bright-dark box, all at least partially validated tests of anxiety (Belzung and Griebel, 2001; Bourin, 2015; Bourin and Hascoët, 2003; Calabrese, 2008; Campos et al., 2013; Crawley, 1985; Dawson and Tricklebank, 1995; Ennaceur and Chazot, 2016; File, 1982, 2001; File and Wardill, 1975; Graeff et al., 1998; Haller et al., 2013; Hascoët et al., 2001; Hogg, 1996; Kliethermes, 2005; Kulkarni and Sharma, 1991; Pinheiro et al., 2007; Ramos, 2008; Rodgers and Dalvi, 1997; Roth and Katz, 1979; Tsang and Ho, 2010; Wall and Messier, 2001; Walsh and Cummins, 1976). Functional interactions exist between open-field, elevated plus-maze, and emergence tests, the latter being an adaptation of defensive withdrawal. Indeed, open-field, elevated plus-maze, and emergence measures were interrelated in $\mathrm{C} 57 \mathrm{BL} / 6 \mathrm{~J}$ and $\mathrm{BALB} / \mathrm{C}$ mice either uninjected (Lalonde and Strazielle, 2008) or injected with GABA-anxiolytic agents (Lalonde and Strazielle, 2010, 2012). For uninjected mice in the entire sample, ambulation and rears in the open-field were positively correlated with open and enclosed arm visits of the elevated plus-maze. Ambulatory movements, stereotyped movements, and rears in the open-field were negatively correlated with emergence latencies. Significant correlations were also found between emergence latencies and exploration of the elevated plus-maze in chlordiazepoxide- or ethanol-treated mice (Lalonde and Strazielle, 2010, 2012). Likewise, significant correlations were obtained in C57BL/6J and BALB/c mice between open-field and elevated plus-maze measures based on principal component analyses (Carola et al., 2002). Open-field activity was also correlated with home-cage activity in a population of C57BL/6J, 129X1/SvJ, and 129P3/J mice (Tang and Sanford, 2005). Moreover, time spent in open arms of the 
elevated plus-maze was positively correlated with time spent in the white compartment of the light-dark box as well as number of head dips in the hole-board by CD1 mice, the latter two variables being also positively intercorrelated (do-Rego et al., 2006). Factor analyses on six inbred rat strains revealed one factor with high loadings for center of the open-field, open arms of the elevated plus-maze, and white compartment of the light/dark box, variables related to approach/avoidance of aversive stimuli (Ramos et al., 1997). On the contrary, open-field and elevated plusmaze measures were not intercorrelated in rats of a single strain (Sudakov et al., 2013).

A physiological convergence between open-field and elevated plus-maze tests was reported with respect to body surface temperatures in domestic mice of wild origin (Lecorps et al., 2016). Initial body temperatures measured by infrared thermography at the start of open-field and elevated plus-maze procedures predicted the levels of exploration in each test. Moreover, rats with high open-field activity were characterized by a greater variability in post-test heart rate relative to those with low activity (Kur'yanova et al., 2015).

In view of inter-test correlations of variable strength, one should expect common effects in regard to $\mathrm{CRH}, \mathrm{ACTH}$, and corticosterone. A limiting factor is the interlaboratory variability in some tests of exploratory activity. Despite the use of a standard protocol, differences in elevated plus-maze and open-field data were reported in different laboratories in a population of $\mathrm{A} / \mathrm{J}, \mathrm{BALB} / \mathrm{cByJ}, \mathrm{C} 57 \mathrm{BL} / 6 \mathrm{~J}$, DBA/2J, 129/Sv-ter, and 129/SvEvTac inbred mouse strains, the F2 hybrid cross of C57BL/6J and DBA/2J, and the Htr1b null mutant lacking the 5HT1B receptor maintained on the 129/Sv-ter background (Crabbe et al., 1999). In another standard protocol, interlaboratory differences in elevated plus-maze though not open-field data 
were reported in C57BL/6N mice (Lewejohann et al., 2006). Subtle differences in the way experimenters handle mice appear responsible for interlaboratory differences in these two tests (Bohlen et al., 2014).

\section{Open-field}

\subsection{General activity}

The open-field test can be measured under either novel or familar conditions depending on whether the animal had been previously adapted to the apparatus (Walsh and Cummins, 1976). Exposure to a novel open-field raised plasma corticosterone levels in mature (Campbell et al., 2004; Marin et al., 2007) and onemonth-old (Suchecki et al., 2000) rats, in the latter group plasma ACTH levels increasing as well. Restraint or variable stress conditions prior to open-field exposure further increased plasma corticosterone levels (Marin et al., 2007). Plasma corticosterone levels were negatively correlated with open-field activity in control but not pre-stressed rats. Thus, open-field exposure appears as a mildly stressful procedure and rats with the least activity had maximal plasma corticosterone levels. The corticosterone response to open-field exposure was attenuated in Pacap null mutant mice lacking pituitary adenylate cyclase-activating polypeptide (PACAP, Tsukiyama et al., 2011), an ACTH releaser (Vaudry et al., 2009). The corticosterone response was not attenuated in these mutants under cold or ether stress, indicating selectivity to the open-field paradigm (Tsukiyama et al., 2011). In addition, open-field exposure elevated CRHR1 expression in hypothalamus and frontal cortex in rats but decreased it in hippocampus (O'Malley et al., 2014).

\subsubsection{CRHR agonists and antagonists}

Kalin et al. (1983) first reported on the behavioral effects of $\mathrm{CRH}$, namely huddling and lying down behaviors in monkeys, an anxiogenic-like pattern confirmed 
by studies in rodents exploring the open-field as first reviewed by Koob and Bloom (1985). Indeed, icv-injected CRH decreased motor activity in a novel open-field (Bakke et al., 1990; Campbell et al., 2004; Koob and Thatcher-Britton, 1985; Sutton et al., 1982; Venihaki et al., 2004). This result appears selective for $\mathrm{CRH}$ in that icv injections of neuromedin S, another activator of the HPA system, had no effect in a novel open-field (Jaszberenyi et al., 2007). In one study (Song et al., 1995), icvinjected $\mathrm{CRH}$ increased activity in a novel open-field, but this effect was seen after four daily injections. Usually, icv-injected $\mathrm{CRH}$ increases motor activity in a familiar open-field (Butler et al., 1990; Jones et al., 1998; Koob and Thatcher-Britton, 1985; Menzaghi et al., 1994; Spina et al., 1996, 2000; Sutton et al., 1982; Zorrilla et al., 2002), consistent with increased arousal. The activational effect in a familiar openfield is independent of corticosterone, since it was found in hypophysectomized rats (Eaves et al., 1985). In addition to familiarity, whether CRH increases or decreases activity depends on dose level (Dunn and Berridge, 1990) and the light-dark cycle (Valdez et al., 2002). In particular, icv-administered CRH decreased activity in a novel open-field during the light cycle but increased it in the dark cycle (Valdez et al., 2002). CRH-induced activation in the familiar open-field was attenuated by icv administration of CRHR antagonists such as alpha-helical CRH-9-41 (Britton et al., 1986; Menzaghi et al., 1994; Spina et al., 2000) and D-Phe-CRH-12-41 (Menzaghi et al., 1994; Spina et al., 2000) as well as a more specific CRHR1 antagonist, antalarmin (Zorrilla et al., 2002). But when antisense oligodeoxynucleotides corresponding to either CRHR1 or CRHR2 mRNA were infused into the lateral ventricle of rats via osmotic minipumps over 5 days, neither had any effect (Liebsch et al., 1999), presumably because blocking one receptor was compensated by the other. 
In a similar manner to $\mathrm{CRH}$, icv-injected urocortin-1, mostly a CRHR2 agonist, reduced mouse exploratory activity in a novel open-field, an effect reversed by ipinjected diazepam or icv-injected alpha-helical CRH-9-41 (Moreau et al., 1997). Likewise, icv-administered urocortin-2, another CRHR2 agonist, decreased activity in a novel open-field (Skorzewska et al., 2011). In addition, icv-administered urocortin-1 and urotensin, yet another CRHR2 agonist, increased activity in a familiar open-field (Jones et al., 1998; Spina et al., 1996), as did the CRHR2 agonist, sauvagine (Jones et al., 1998). But yet icv-administered urocortin-2 increased activity in a familiar openfield only during the light not the dark part of the diurnal cycle (Valdez et al., 2002), perhaps because of a ceiling effect. Icv-injected urocortin-3, also a selective CRHR2 agonist, even decreased photocell counts in a familiar open-field during the dark part of the diurnal cycle (Valdez et al., 2003).

Pharmacological studies are supplemented by Crh gene manipulations. Like $\mathrm{CRH}$ administration, three different $\mathrm{Crh}$ transgenic mouse models overexpressing the rat version of the gene had lower motor activity than wild-type in a novel open-field (Kasahara et al., 2007; Stenzel-Poore et al., 1994; van Gaalen et al., 2002). On the contrary, Crh null mutant mice lacking $\mathrm{CRH}$ displayed no change in motor activity in a novel open-field compared to wild-type with or without restraint stress, so that a compensatory mechanism appears to be at work, one or more genes taking over from the missing one (Dunn and Swiergiel, 1999). However, as expected, Crhr1 null mutant mice lacking CRHR1 were more active than wild-type in a novel open-field (Timpl et al., 1998), as were conditional Crhr1 null mutant mice lacking CRHR1 in the limbic system (Müller et al., 2003). In contrast, Crhr2 null mutants did not differ from controls on motor activity in a novel open-field (Coste et al., 2000). 
The anatomical basis of $\mathrm{CRH}$-mediated effects on general activity has been initiated (Table 1). As found when injected icv, $\mathrm{CRH}$ injected in the amygdala, a brain area involved in many types of fear-related responses (Tovote et al., 2015), decreased horizontal activity and rearing in a novel open-field in rats (Liang and Lee, 1988), as did CRH injections in the Fr2 region of the frontal cortex (Zieba et al., 2008). In contrast, $\mathrm{CRH}$ injected in the ventral tegmental area increased horizontal and vertical photocell counts in a novel open-field (Kalivas et al., 1987), although it usually does so in a familiar one. The more specific CRHR2 agonist, urocortin-1, administered in the supraoptic nucleus of the hypothalamus increased rearing and grooming episodes in a familiar open-field but without affecting locomotion and pretreatment with the CRHR2 antagonist, astressin-2B, normalized those effects (Fatima et al., 2010).

\subsubsection{Other stress-related peptides}

Ghrelin promotes growth hormone secretion via activation of the growth hormone secretagogue receptor in hypothalamus and pituitary gland (Chanoine et al., 2009). Unlike $\mathrm{CRH}$, icv-injected ghrelin increased horizontal motor activity in a novel open-field in rats (Carlini et al., 2002). However, icv-administered ghrelin decreased locomotor activity in a novel open-field when rats were evaluated over an

unusually long period (20 hrs) (Tang-Christensen et al., 2004), more than the $10 \mathrm{~min}$ used in the previous study. The ghrelin-induced increase in square crossings and rearing in the novel open-field was mitigated by icv-injected alpha-helical CRH-9-41, the CRHR antagonist (Jaszberenyi et al., 2006).

\subsubsection{Glucocorticoids and mineralocorticoids}

Glucocorticoids and mineralocorticoids alter open-field activity depending on number of injections and dose levels. Unlike $\mathrm{CRH}$, acute $5 \mathrm{mg} / \mathrm{kg}$ ip corticosterone 
increased rat horizontal and vertical activity in a novel open-field (Tenk et al., 2006). Horizontal activity was also elevated in a novel though not a familiar open-field after acute 2.5 or 5 mg/kg ip corticosterone (Sandi et al., 1996a). Moreover, horizontal activity increased in a novel open-field after acute $100 \mathrm{mg} / \mathrm{kg}$ sc corticosterone (Dickinson et al., 1985). On the contrary, no effect was found after acute 1 or 10 $\mathrm{mg} / \mathrm{kg}$ ip corticosterone (Sandi et al., 1996a) or $2 \mathrm{mg} / \mathrm{kg}$ ip corticosterone (Steketee and Goeders, 2002) in a novel open-field. In an opposite manner to corticosterone, ip-injected metyrapone, a glucocorticoid synthesis inhibitor, decreased horizontal activity in a novel open-field (Marinelli et al., 1997), a result later confirmed and found as well in regard to vertical activity (Canini et al., 2009). But neither RU38486 (mifepristone), the glucocorticoid receptor antagonist, nor RU28318 (spironolactone), the mineralocorticoid receptor antagonist, had any effect on corticosterone-induced activation (Sandi et al., 1996a). Instead, ip or icv injections of the nitric oxide inhibitor, NG-nitro-L-arginine methyl ester (L-NAME), was effective in preventing corticosterone-induced activation (Sandi et al., 1996b). But when acute corticosterone was infused in the nucleus pontis oralis (Table 1), distance traveled increased in a novel open-field and this effect was prevented by pretreatment in the same nucleus with either mifepristone or spironolactone (Sandoval-Herrera et al., 2011).

While examining the effects of chronic corticosterone, one must take into account its synaptotoxic effects in the hippocampus when administered at $40 \mathrm{mg} / \mathrm{kg}$ sc for 60 days (Tata et al., 2006). On one hand, a long-lasting $20 \mathrm{mg}$ pellet of corticosterone for 21 days decreased motor activity in C57BL/6J and C57BL/6N mice exploring a novel open-field (Sturm et al., 2015). A decrease was also found in rats exploring a novel open-field after 4-day treatment of $100 \mathrm{mg} / \mathrm{kg} \mathrm{sc}$ corticosterone 
(Dickinson et al., 1985). On the other hand, a long-lasting $200 \mathrm{mg}$ pellet for 21 days had no such effect in rats (Diniz et al., 2011). Although $40 \mathrm{mg} / \mathrm{kg}$ sc corticosterone for 21 days caused hypoactivity in a novel open-field in rats in one study (Lee et al., 2013), the same dose, treatment time, open-field condition, and species had no effect in another (Marks et al., 2009), and neither did a 22-day period of $40 \mathrm{mg} / \mathrm{kg} \mathrm{sc}$ corticosterone (Kalynchuk et al., 2004). In addition, 25 mg/kg sc corticosterone for 28 days did not affect horizontal and vertical activity (Pego et al., 2008). Nevertheless, home-cage hypoactivity was found in C57BL/6Ntac mice treated for 8 weeks with corticosterone in their drinking water (Rainer et al., 2012). While acute corticosterone sometimes increases activity in a novel open-field, chronic corticosterone sometimes causes the opposite effect, either effect seeming to appear within narrow dose ranges. Corticosterone-mediated hypoactivity may be more sensitive in more active mouse strains such as C57BL/6J than less active ones.

In addition to mature animals, the effects of chronic corticosterone have been examined during the neonatal period. Corticosterone administered sc post-partum in the mother rat increased offspring peripheral crossings in a novel open-field on postnatal (P) days 24-26 (Brummelte et al., 2006). These findings are consistent with those of elevated wheel-running activity on P14-26 after long-lasting corticosterone pellet treatment on P2-14 in mice (Howard and Granoff, 1968) and elevated horizontal and vertical activity on P18-21 after acute dexamathesone sc treatment on P7 in rats (Ferguson and Holson, 1999). However, a long-lasting pellet of corticosterone on P2-14 reduced mouse open-field activity at 2 and 4 months of age (Howard and Granoff, 1968). Likewise, when rat dams were injected sc with dexamethasone thoughout pregnancy or only the final week, adult offspring was less active than vehicle-treated rats (Welberg et al., 2001). 


\subsection{Center zone exploration}

The evaluation of anxiety levels in the open-field can best be ascertained by measuring central as opposed to peripheral exploration, the former being a more anxiogenic area as a result of the thigmotaxic (wall-hugging) tendencies of rats and mice to ensure survival in the wild (Choleris et al., 2001; Prut and Belzung, 2003). When center measures are used, the open-field is almost always unfamiliar to the animal to maximize anxiety levels. Sometimes, an object is introduced in the center so that object exploration can be measured in addition to the exploration of place. Benzodiazepines with anxiolytic properties in other assays increase entries or time spent in the center region, whereas antagonists at these receptors decrease these measures.

In an opposite manner to benzodiazepines, restraint stress decreased center region entries and duration in mice (Henry et al., 2006). However, no such effect in mice was found on center zone duration in another study (Yoon et al., 2014). Chronic unpredictable mild stress even increased time spent in the center of the open-field (Liu and Zhou, 2012). Effects on center region activity are also counter-intuitive. Instead of decreasing center square activity, noise-light stress increased it (Roth and Katz, 1979), as did either restraint or footshock stress (Lee et al., 1986; Lee and Tsai, 1989), presumably because stressed animals run around to escape the novel environment. Indeed, restraint or footshock stress increased peripheral activity, though in a different time-frame than the increase in central activity (Lee et al., 1986).

The degree of center area exploration depends on rodent strain. For example, F344/N rats had more center region activity than Harlan Sprague-Dawley rats (Sternberg et al., 1992). It also depends on neonatal handling, a critical modulator of the HPA response (Meaney et al., 1995; Zaletel et al., 2016), generally leading to 
anxiolytic effects (Raineki et al., 2014). Relative to controls, neonatally handled rats had higher glucocorticoid receptor binding in the hippocampus (Meaney et al., 1989), lower glucocorticoid secretion in response to stress (Meaney et al., 1988), and a higher degree of exploration in the center of the open-field (Caldji et al., 2000; Madruga et al., 2006; Padoin et al., 2001), the latter result also found in boars (Weaver et al., 2000).

\subsubsection{CRH agonists and antagonists}

After injection via the icv route in rats, $\mathrm{CRH}$ decreased approaches to a food pellet placed in the center of the open-field and increased grooming, concordant with an anxiogenic response (Britton et al., 1982). Icv-injected $\mathrm{CRH}$ reduced center region entries in rats without affecting peripheral activity, an anxiogenic-like pattern reversed by icv administration of the CRHR antagonist, alpha-helical CRH-9-41 (Kumar and Karanth, 1996) or antisense targeting with oligonucleotides against CRHR1 mRNA (Skutella et al., 1998). Icv-injected CRH also decreased center zone duration in rats (Campbell et al., 2004) but increased center zone activity without affecting peripheral activity in the genetically anxious Balb/c mouse strain, an effect reversed by ipinjected diazepam (Lee et al., 1987). Moreover, icv-administered CRH increased central but not peripheral activity in hypophysectomized rats (Veldhuis and De Wied, 1984). Thus, like stress, CRH appears to increase activity in the center of the openfield despite decreasing entries and duration. On the contary, null mutant mice lacking $\mathrm{CRH}$ binding protein did not differ from wild-type in center zone entries and duration (Karolyi et al., 1999), indicating a compensatory action by another gene. A cue may be provided by the increase in center zone distance and duration noted under icv-administered $\mathrm{CRH}$ after acute iv administration of teneurin C-terminal associated peptide-1 (TCAP-1) (Al Chawaf et al., 2007). 
Like $\mathrm{CRH}$, icv-administered cortagine, a CRHR1 agonist (Farrokhi et al., 2007), decreased center zone duration in C57BL/6J mice (Sherrin et al., 2009). Uncertainty arises as to the influence of CRHR2. Icv-injected urocortin-3, the CRHR2 agonist, augmented center region entries and duration in C57BL/6 mice (Venihaki et al., 2004). Yet icv-injected anti-sauvagine-30, the CRHR2 antagonist, also increased center zone duration in Balb/c mice (Pelleymounter et al., 2002). This paradox may be due to the different mouse strains used, as C57BL/6 mice are generally less anxious than Balb/c (Lalonde and Strazielle, 2008). Although one Crhr2 null mutant mouse model lacking CRHR2 showed more center zone entries than wild-type (Kishimoto et al., 2000), a different Crhr2 knockout mouse model showed fewer center region entries and lesser duration (Bale et al., 2000) while a third did not differ from controls on center zone duration (Coste et al., 2000).

Limbic regions are implicated in $\mathrm{CRH}$-mediated effects on center region behaviors (Table 2). CRH augmented center zone activity in Balb/c mice injected in hippocampus but not in amygdala or caudate nucleus (Lee and Tsai, 1989). Lentivirus-induced $\mathrm{CRH}$ overexpression for 4 months in the central nucleus of the amygdala but not the bed nucleus of the stria terminalis increased center region entries in non-stressed rats as well as center region entries and duration in rats preexposed to restraint stress (Regev et al., 2011). Yet acute CRH knockdown with RNA oligonucleotides in the central nucleus of the amygdala had no effect on center zone entries and duration, implying the existence of a compensatory mechanism (Callahan et al., 2013). The CHRHR2 agonist, urocortin-2, infused in the lateral septum potentiated immobilization stress-induced decreases in center zone entries and duration in mice (Henry et al., 2006). 
When basal ganglia are examined, $\mathrm{CRH}$ infused in the shell region of the nucleus accumbens reduced center zone duration without affecting general ambulation in the open-field (Chen et al., 2012). In an opposite manner, the CRHR1 antagonist, NBI30775, infused in the external part of the globus pallidus increased center region entries (Sztainberg et al., 2011). Yet, paradoxically, knockdown of CRHR1 mRNA expression by a lentiviral-based system in the same brain region decreased center region entries without changing total distance traveled (Sztainberg et al., 2011).

In summary, the hippocampus, amygdala, lateral septum, nucleus accumbens, and lateral globus pallidus appear involved in $\mathrm{CRH}$-mediated anxiety in the central zone of the open-field. The amygdala and hippocampus are anatomically interrelated and the main output from the hippocampal formation, the subiculum, strongly projects to lateral septum and nucleus accumbens (Witter and Amaral, 2004). The lateral septum mainly expresses CRHR2 rather than CRHR1 (Van Pett et al., 2000), which likely explains the anxiogenic response of the CHRHR2 agonist. Of note as well are findings that the lateral septum receives dense projections from the medial amygdala (Canteras et al., 1995) and the bilateral connections between the lateral septum and the hypothalamus (Risold and Swanson, 1997). The effects of the lateral globus pallidus may be explained by its high levels of CRHR1 expression and its afferents from the central amygdala (Shinonaga et al., 1992).

\subsubsection{Glucocorticoids and mineralocorticoids}

On one hand, acute 20 but not $5 \mathrm{mg} / \mathrm{kg}$ sc corticosterone increased center region entries, duration, and distance travelled in rats (Skorzewska et al., 2006). Center zone duration also increased after acute $1 \mathrm{mg} / \mathrm{kg} \mathrm{sc}$ corticosterone in rats when an object was placed inside, an effect prevented by icv-administered 
spironolactone, the mineralocorticoid receptor antagonist, but not by mifepristone, the glucocorticoid receptor antagonist (Oitzl et al., 1994). On the other hand, acute 0.5 $\mathrm{mg} / \mathrm{kg}$ ip corticosterone decreased center zone duration in C57BL/6 mice (Espallergues et al., 2012). In contrast to acute administration, chronic corticosterone mostly causes anxiogenic effects. In particular, 5 and $20 \mathrm{mg} / \mathrm{kg} \mathrm{sc}$ corticosterone for 25 days decreased plasma corticosterone concentrations (via feedback inhibition) in rats and decreased center zone entries, duration, and distance without affecting total distance traveled (Skorzewska et al., 2006). Likewise, 7-day corticosterone treatment in drinking water decreased center zone entries and duration in C57BL/6NTac mice (David et al., 2009) and 21-day corticosterone treatment in drinking water decreased center zone duration and elevated latencies before entering the center zone in rats (Donner et al., 2012). The 21-day corticosterone treatment in drinking water also decreased center region entries without changing general activity, an effect prevented by combined sc treatment with mifepristone and spironolactone (Fan et al., 2014). Although a long-lasting corticosterone pellet for 21 days decreased center zone entries in C57BL/6N mice, it had no effect on the closely allied C57BL/6J strain (Sturm et al., 2015). Neither did a long-lasting corticosterone pellet for 21 days had any effect in C57BL/6J mice on center zone duration (Demuyser et al., 2016). In addition, $40 \mathrm{mg} / \mathrm{kg} \mathrm{sc}$ corticosterone for 21 days had no effect in rats on center zone entries (Kalynchuk et al., 2004) or center zone entries, rearing, or time spent freezing (Gregus et al., 2005), and at $20 \mathrm{mg} / \mathrm{kg}$ sc on center zone duration (Yoon et al., 2014). Moreover, $25 \mathrm{mg} / \mathrm{kg}$ sc corticosterone for 28 days did not affect center zone duration in rats (Pego et al., 2008), and neither did $20 \mathrm{mg} / \mathrm{kg} \mathrm{sc}$ corticosterone for 40 days (Liu and Zhou, 2012). Thus, corticosterone-mediated anxiogenic effects depend on subtle differences in mouse strains as well as narrow dose ranges and treatment time. 
Center zone duration decreased in young offspring of adrenalectomized dams replaced with corticosterone relative to sham-operated controls (Wilcoxon et al., 2007). But offspring from corticosterone-treated dams had equivalent central zone crossings on P24-26 relative to control offspring (Brummelte et al., 2006). Dexamethasone administered sc in neonatal rats and tested at 2.5-3 months had higher start latencies from the center region while the more slowly metabolized ACTH-(4-9) analogue, ORG2766, had no such effect (Felszeghy et al., 1993). Likewise, ORG2766 injected sc in neonatal rats and tested at 3 months had no effect on center zone entries and duration (Horvath et al., 1999).

The icv administration of obestatin, a peptide found in the pituitary gland, decreased central ambulation in the open-field, an effect reversed by [d-Lys3]GHRP6, a ghrelin receptor antagonist (Szakacs et al., 2015). Rats chronically administered with osmotic minipumps with the mineralocorticoid receptor agonist, aldosterone, entered less often, spent less time, and were less active in the central area (Hlavacova and Jezova, 2008).

The anatomical basis of glucocorticoid and mineralocorticoid receptormediated effects has been initiated (Table 2). Infusion of viral-mediated short hairpin RNA targeting against the glucocorticoid receptor in prelimbic cortex after chronic variable stress increased center and peripheral activity without changing center region duration, while infusion in infralimbic cortex had no impact on center zone duration or activity (McKlveen et al., 2013). There was also no change in open zone duration after viral-mediated deletion of glucocorticoid receptors in the dorsal raphe (Vincent et al., 2014). The influence of the mineralocorticoid as opposed to the glucocorticoid receptor on this behavior is indicated by the finding that intrahippocampal infusion of spironolactone but not mifepristone increased center 
zone duration (Bitran et al., 1998). The anxiolytic action of spironolactone was eliminated in adrenalectomized rats or those pretreated with an ip injection of dexamethasone, perhaps because complete occupation of the mineralocorticoid site is necessary for the anxiolytic effect to occur, a state presumably compromised by adrenalectomy or occupation by a glucocorticoid receptor agonist. On the contrary, chronic sc treatment with another mineralocorticoid receptor antagonist, eplerenone, had no effect on center zone entries (Hlavacova et al., 2010).

\section{Hole-board}

As found in the open-field (Campbell et al., 2004), exposure to a hole-board increased plasma corticosterone concentrations in rats (File, 1982), a noveltyinduced effect potentiated by anxiogenic agents such as the benzodiazepine receptor inverse agonist, FG7142, as well as benzodiazepine receptor antagonists, CGS8216 and Ro15-1788 (flumazenil) (Pellow and File, 1985). In an opposite mannner, divers agonists of the gamma-amino-butyric acid (GABA)-benzodiazepine receptor complex increased hole-board exploration in mice (Bhatt et al., 2013; Bilkei-Gorzoa and Gyertyan, 1996; (do-Rego et al., 2006; Kliethermes and Crabbe, 2006; Nolan and Parkes, 1973; Takeda et al., 1998) and rats (Seo et al., 2007). One of these, chlordiazepoxide, increased hole-board exploration under bright but not dark conditions when the level of exploration was maximal and thus liable to a ceiling effect (Bilkei-Gorzo and Gyertyan, 1996). Rather than being only an estimate of anxiety, head-dipping sometimes constitutes a component of escape attempt depending on the degree of environmental stress such as room brightness (BilkeiGorzo and Gyertyan, 1996; Brown and Nemes, 2008).

\subsection{CRHR agonists and antagonists}


In an opposite manner to benzodiazepines, icv-injected $\mathrm{CRH}$ reduced holeboard exploration irrespective of whether the rats were hypophysectomized (Adamec et al., 1991). Also as expected, hole pokes diminished in transgenic mice overexpressing Crh (van Gaalen et al., 2002).

\subsection{Glucocorticoids and mineralocorticoids}

Icv administration of urotensin-2, which decreases corticosterone secretion from cultured adrenocortical cells, an effect abolished by an antagonist of the urotensin receptor (Albertin et al., 2006), decreased head-dips without affecting motor activity in mice (do-Rego et al., 2005; Matsumoto et al., 2004).

\section{Multicompartment chamber}

The exploration of novel stimuli placed in a multicompartment chamber has been used to estimate anxiety levels (Berridge and Dunn, 1987). The main measure used is time spent in contact with novel stimuli.

\subsection{CRHR agonists and antagonists}

Either icv-administered $\mathrm{CRH}$ or restraint stress reduced times normal (Berridge and Dunn, 1987) or hypophysectomized (Berridge and Dunn, 1989) mice spent in contact with novel stimuli placed in the multicompartment chamber. The anxiogenic effect of restraint stress was reversed by icv administration of the $\mathrm{CRH}$ receptor antagonist, alpha-helical CRH-9-41 (Berridge and Dunn, 1987). Nevertheless, Crh-deficient mice behaved normally in the multicompartment chamber with or without restraint stress, implying a compensatory action from another gene (Dunn and Swiergiel, 1999; Weninger et al., 1999).

To investigate the anatomical basis of $\mathrm{CRH}$-induced downregulation of exploratory activity in the multicompartment chamber, cold cream plugs were applied to different regions in rat brain (Spadaro et al., 1990). When the cerebral aqueduct 
was blocked, $\mathrm{CRH}$ injected in the lateral but not the fourth ventricle decreased exploratory behavior. Blocking the third ventricle prevented the effect of lateral ventricle administration, especially the anteroventral portion, where lies the organum vasculosum laminae terminalis (OVLT), involved in the pressor response. It is also possible that CRHR1 located on paraventricular $\mathrm{CRH}$ neurons affected anxiety via positive feedback control (Mansi et al., 1996).

\subsection{Glucocorticoids and mineralocorticoids}

To our knowledge, the effects of glucocorticoids and mineralocorticoids on the multicompartment chamber have not been examined.

\section{Elevated plus-maze}

The elevated plus-maze contains two anxiogenic open arms intersecting two safer enclosed arms (Fernandes and File, 1996; Hogg, 1996; Kulkarni and Sharma, 1991; Pellow et al., 1985; Walf and Frye, 2007). To prevent rodents from falling off the open arms, tiny ledges are put up along the sides, a procedure that subtly influences drug effects in multiple trial paradigms (Fernandes and File, 1996). As found in the open-field (Campbell et al., 2004) and hole-board (Pellow and File, 1985), rats continuously exposed to the open arms had higher plasma corticosterone levels than those continuously exposed to control conditions, in this case either the enclosed arms (Pellow et al., 1985) or their home-cage (File et al., 1994). Elevated plus-maze exposure also increased plasma ACTH (Appenrodt et al., 1999; Keck et al., 2001) and CRH mRNA levels in the central nucleus of the amygdala (Shepard et al., 2003). The paradigm is susceptible to strain differences, since, for example, open arm exploration was higher in C57BL/6JOlaHsd than DBA/2OlaHsd mice (Thoeringer et al., 2007) and Wistar or Wistar Kyoto than F344 rats, perhaps due to the higher basal $\mathrm{CRH}$ mRNA levels found in the central nucleus of the amygdala of Wistar 
Kyoto (Shepard and Myers, 2008). The open/total arm ratio of exploration has pharmacological validity as a specific measure of anxiety, since higher values were obtained after the administration of benzodiazepines (Bhatt et al., 2013; Conti et al., 1994; Griebel et al., 1998; Hodgson et al., 2007; Lalonde and Strazielle, 2010; Lelas et al., 2004; Millan et al., 2001; Pellow and File, 1985; Ramos et al., 1997; Rochford et al., 1997; Seo et al., 2007; Stock et al., 2000), ethanol (Durcan et al., 1988), and divers olfactory substances (Tsang and $\mathrm{Ho}, 2010$ ).

As found for center zone exploration in the open-field (section 2.2), neonatal handling increased open arm exploration (Raineki et al., 2014). In contrast, restraint, resident intruder, or swim stress decreased open arm exploration (Heinrichs et al., 1994, 2002), as did footshock stress (Calvo and Volosin, 2001; Lim et al., 2012) or a combination of stress conditions (Han et al., 2014). Stress-induced effects seem mediated by corticosterone because the restraint stress-induced decrease in open arm entries and duration was prevented by metyrapone, a 11-ß-hydroxylase inhibitor that blocks corticosterone synthesis (Calvo and Volosin, 2001). In addition, the anxiogenic action of resident intruder stress (Calfa et al., 2006, 2007) was prevented by the glucocorticoid receptor antagonist, mifepristone, but not the mineralocorticoid receptor antagonist, ZK91587, injected in the lateral septum (Calfa et al., 2006). Moreover, the swim stress-induced decrease in open arm time was counteracted by the CRHR1 antagonist, CP376395, but not the CRHR2 antagonist, astressin-2B, injected in the bed nucleus of the stria terminalis (Tran et al., 2014).

\subsection{CRH receptor agonists and antagonists}

\subsubsection{Intracerebroventricular and peripheral injections}

In an opposite fashion to benzodiazepines, icv-administered $\mathrm{CRH}$ has often been shown to reduce open arm exploration in the elevated plus-maze (Adamec and 
McKay, 1993; Adamec et al., 1991; Baldwin et al., 1991; Bruchas et al., 2009; Buwalda et al., 1997; Jones et al., 1998; Kagamiishi et al., 2003; Kishimoto et al., 2000; Moreau et al., 1997; Pelleymounter et al., 2004; Rodi et al., 2008; Song et al., 1995; Spina et al., 1996, 2000; Tan et al., 2008; Tezval et al., 2004; Venihaki et al., 2004), an effect mitigated by icv-administered CRHR antagonists such as alphahelical CRH-9-41 (Kagamiishi et al., 2003) and astressin (Spina et al., 2000), CRHR1 antagonists such as po (Okuyama et al., 1999) or ip (Zorrilla et al., 2002) administered antalarmin and po-administered CRA1000H2SO4 or CRA1001H2SO4 (Okuyama et al., 1999) as well as icv-injected antisense targeting with oligodeoxynucleotides against CRHR1 mRNA (Skutella et al., 1998). The anxiogenic impact of icv-administered $\mathrm{CRH}$ was observed regardless of whether rats were hypophysectomized and therefore independent of corticosterone (Adamec and McKay, 1993).

Other CRHR1 agonists possess anxiogenic properties in the elevated plusmaze. In particular, icv-administered stressin-1 decreased open arm duration (Bruchas et al., 2009) and icv-administered cortagine decreased open arm entries and duration (Sherrin et al., 2009; Tezval et al., 2004). There is mixed evidence regarding CRHR2 agonists. Open arm exploration decreased after icv-administered urocortin-1 (Jones et al., 1998; Moreau et al., 1997; Spina et al., 2002). In the same maze configuration, urocortin-1 had this anxiogenic effect at 30 (Spina et al., 2002) but not 5 (Spina et al., 1996) min after injection. Although open arm duration declined after icv-administered urocortin-2 in Balb/c mice (Pelleymounter et al., 2004), icvinjected urocortin-3 had no effect in C57BL/6 mice either alone or after restraint stress (Venihaki et al., 2004). There is even evidence that icv-injected urocortin-2 (Valdez et al., 2002) or urocortin-3 (Valdez et al., 2003) in rats or urocortin-3 in mice 
(Telegdy and Adamik, 2013) increased open arm exploration, although the latter had no effect in subsequent studies (Bruchas et al., 2009; Cipriano et al., 2016; Venihaki et al., 2004).

In contrast to agonists, CRHR antagonists possess anxiolytic properties in the elevated plus-maze, though dependent on post-injection interval and rodent strain. Indeed, icv-injected $50 \mu \mathrm{g}$ alpha-helical $\mathrm{CRH}-9-41$ increased open arm duration in Wistar rats when tested at the $60 \mathrm{~min}$ (Adamec et al., 1991) but not the $30 \mathrm{~min}$ (Baldwin et al., 1991) post-injection interval. Although icv-injected alpha-helical $\mathrm{CRH}$ 9-41 increased open arm entries and duration in Balb/c mice, no such effect occurred in NIH Swiss, CD, or CF-I mice (Conti et al., 1994). Nevertheless, anxiolytic effects are found with CRHR1 antagonists, since po-administered DMP904 increased open arm duration (Lelas et al., 2004) and ip-injected CP-154,526, an analog of antalarmin (Schulz et al., 1996 ; Seymour et al., 2003), increased open arm entries and duration (Lundkvist et al., 1996),. But other studies have shown no effect in the elevated plusmaze after ip-injected CP-154,526 (Griebel et al., 1998 ; Hodgson et al., 2007; Millan et al., 2001) or antalarmin (Zorrilla et al., 2002) when no pre-stress condition was applied, and neither did sc-injected DMP695 (Millan et al., 2001), ip-injected CRA1000 (Harro et al., 2001), and R121919 administered via minipump (Gutman et al., 2011) or sc (Gutman et al., 2008). However, sc-injected R121919 increased open arm entries and duration in Wistar rats bred for high anxiety (Keck et al., 2001). Paradoxically, po-administered GSK876008 decreased open arm duration in rats but yet blocked the decrease caused by calcitonin gene-related peptide infused in the bed nucleus of the stria terminalis (Sink et al., 2013a).

When CRHR2 antagonists were examined, icv-administered anti-sauvagine30 increased open arm duration in Balb/c mice (Pelleymounter et al., 2002) or rats 
(Takahashi et al., 2001) but decreased open arm entries and duration in C57BL/6J mice (Kishimoto et al., 2000). Open arm duration also increased after icvadministered astressin in Balb/c mice (Pelleymounter et al., 2002). But as with other $\mathrm{CRHR}$ antagonists, negative results have appeared regarding icv-administered astressin-2B and antisauvagine-30 in rats (Zorrilla et al., 2013).

In general, the anxiolytic profile of CRHR antagonists appears more evident when stressors are applied prior to elevated plus-maze exposure. In particular, poadministered R278995/CRA0450 counteracted the swim stress-induced decrease in open arm time but had no effect in non-stressed rats (Chaki et al., 2004). Moreover, icv-injected alpha-helical $\mathrm{CRH}-9-41$ was effective after restraint or swim stress (Heinrichs et al., 1994) and ethanol withdrawal (Baldwin et al., 1991), as was icvinjected alpha-helical CRH-9-41 (Heinrichs et al. 1992; Heinrichs et al. 1994; Menzaghi et al., 1994), D-Phe-CRH-12-41 (Menzaghi et al., 1994), or astressin (Spina et al., 2000) after resident intruder stress. Likewise, po-administered R121919 counteracted the reduction in open arm duration found after restraint stress (Heinrichs et al., 2002) and po-administered antalarmin increased open arm duration after resident intruder stress, though no such effect occurred after po-administered SSR125543A (Griebel et al., 2002).

In line with pharmacologic data, icv-injected antisense targeting with oligodeoxynucleotides against $\mathrm{CRH}$ mRNA in rats subjected to resident intruder stress augmented time spent in open arms compared with sense oligodeoxynucleotide- or vehicle-treated animals (Skutella et al., 1994). Although subchronic icv-injected CRHR2 mRNA antisense oligodeoxynucleotides augmented open arm duration after resident intruder-induced stress, CRHR1 oligodeoxynucleotide infusion did not (Liebsch et al., 1999). Yet open arm duration 
paradoxically decreased in rats not subject to stress but injected icv with CRHR2 antisense oligonucleotides compared with vehicle or scrambled oligonucleotidetreated groups (Isogawa et al., 2003).

In addition to pharmacological or mRNA targeting, genetic information related to $\mathrm{CRH}$ has been provided. As expected, Crh transgenic mice overexpressing the rat version of the gene had shorter open arm duration than non-transgenic controls, an effect reversed by icv-administered alpha-helical-CRH-9-41 (Stenzel-Poore et al., 1994). Also as expected, null mutant mice lacking $\mathrm{CRH}$ binding protein (presumably increasing free $\mathrm{CRH}$ levels) had fewer open arm entries and shorter duration than wild-type (Karolyi et al., 1999). Yet Crh-deficient mouse models did not differ from wild-type in open arm exploration either with or without restraint stress (Dunn and Swiergiel, 1999; Weninger et al., 1999). More in tune with expectations, Crhr1 null mutant mice deficient in CRHR1 showed an anxiolytic-like effect in the elevated plusmaze (Contarino et al., 1999; Gammie and Stevenson, 2006; Smith et al., 1998), though not when tested a few days after post-partum, indicating elimination of the genetic difference through lactation (Gammie et al., 2007). A tendency towards an anxiolytic response $(\mathrm{P}=0.06)$ occurred with conditional Crhr1 null mutant mice lacking CRHR1 in the limbic system (Müller et al., 2003). Although Crhr2 null mutants on a hybrid 129SvJ-C57BL/6J genetic background had fewer entries and spent less time in the open arms (Bale et al., 2000; Kishimoto et al., 2000), no such effect occurred in another Crhr2 knockout on a purer C57BL/6J background (Zorrilla et al., 2013), indicating an interaction between this gene and others.

\subsubsection{Injections in specific brain regions}

The anatomical basis of $\mathrm{CRH}$-mediated anxiogesis on the elevated plus-maze has been examined at the level of the limbic system (Table 3). $\mathrm{CRH}$ infused in the 
basolateral amygdala decreased open arm entries and duration in mice, whereas infusion in the same region of the CRHR1 antagonist, CP376395, but not the CRHR2 antagonist, antisauvagine-30, increased open arm duration (Cipriano et al., 2016), a distinction attributable to the exceptional richness of CRHR1 in this brain region (see section 1.1). Likewise, $\mathrm{CRH}$ infused in the basolateral amygdala decreased open arm duration in rats (Gray et al., 2015). On the contrary, no such effect occurred in rats injected in the basolateral amygdala for five days with or without prior restraint stress, perhaps a sign of rapid tolerance (Daniels et al., 2004). When a lentiviral vector overexpressed $\mathrm{CRH}$ in the central nucleus of the amygdala of female rats before weaning, open arm duration decreased in peripubertal rats (Li et al., 2014). But no such effect occurred after 4-month lentivirus-induced $\mathrm{CRH}$ overexpression in this region in adult mice, a sign of compensation after long-length exposure (Regev et al., 2011). In an opposite fashion to $\mathrm{CRH}$ administration, $\mathrm{CRH}$ knockdown in the central nucleus of the amygdala by a lentivirus increased open arm entries and duration after restraint stress in mice (Regev et al., 2012). Likewise, CRH knockdown with RNA oligonucleotides in the central nucleus of the amygdala increased open arm entries in rats (Callahan et al., 2013). In the case of CRHR antagonists, alpha-helical $\mathrm{CRH}-9$ 41 injected in the central nucleus of the amygdala counteracted the decrease in open arm time after ethanol withdrawal but not in placebo-treated rats (Rassnick et al., 1993). Likewise, subchronic infusion of antisense oligodeoxynucleotides against CRHR1 mRNA in the central nucleus of the amygdala increased open arm duration after resident intruder-induced stress relative to scrambled sequence oligodeoxynucleotide-treated rats and vehicle controls (Liebsch et al., 1995).

Aside from the amygdala, other limbic regions are implicated in $\mathrm{CRH}$-mediated anxiogenesis in the elevated plus-maze. $\mathrm{CRH}$ injected in the ventral hippocampus 
decreased open arm time in rats (Pentkowski et al., 2009). On the contrary, no such effect occurred following intrahippocampal injection of $\mathrm{CRH}$ in Balb/c mice (Radulovic et al., 1999). Instead, CRH decreased open arm entries and duration after administration in the lateral septum, an effect counteracted by CRHR2 antagonists, antisauvagine-30 or astressin (Radulovic et al., 1999). Likewise, the CRHR2 agonist, urocortin-1 (Bakshi et al., 2007) and the CRHR1 agonist, cortagine (Tezval et al., 2004), decreased open arm entries and duration when injected in the lateral septum. $\mathrm{CRH}$ also reduced open arm entries and duration when infused in the bed nucleus of the stria terminalis, an effect inhibited by co-infusion with CP-154,526 but not antisauvagine-30, therefore mediated by CRHR1 (Sahuque et al., 2006). But an opposite conclusion is reached when considering that open arm time decreased after infusion of the CRHR2 antagonist, astressin-2B, in the bed nucleus of the stria terminalis, but not the CRHR1 antagonist, CP376395 (Tran et al., 2014). In three more experiments, negative results have been obtained regarding this brain region. Urocortin-1 administered in the bed nucleus of the stria terminalis had no effect in the elevated plus-maze (Lee et al., 2008) and neither did a lentivirus containing a $\mathrm{CRH}$ specific promoter used to overexpress $\mathrm{CRH}$ in the bed nucleus of the stria terminalis for 14 days (Sink et al., 2013b) or 4 months (Regev et al., 2011).

In addition to the limbic system, midbrain regions are implicated in $\mathrm{CRH}$ mediated anxiogenesis in the elevated plus-maze. Indeed, $\mathrm{CRH}$ infused in the dorsal periaqueductal grey decreased open arm exploration in mice (Borelli and Brandao, 2008) and rats, an anxiogenic effect blocked by injections in the same brain area of the CRHR1 antagonist NBI27914, but not the CRHR2 antagonist, anti-sauvagine-30 (Miguel and Nunes-de-Souza, 2011). Moreover, CRH injected in the dorsal periaqueductal grey potentiated the anxiogenic effect of restraint stress in rats, an 
effect blocked by injecting in the same brain region the non-selective CRHR antagonist, alpha-helical-CRH-9-41 (Martins et al., 1997), which also blocked the anxiogenic effect of restraint stress alone (Martins et al., 2000). In contrast, $\mathrm{CRH}$ administered in the medial raphe, a region that projects $5 \mathrm{HT}$ fibers to dorsal hippocampus and amygdala (Hensler, 2006), had no impact on the elevated plusmaze (Ohnura et al., 2008).

When telencephalic regions are examined, we see that $\mathrm{CRH}$ injected in the shell subregion of the nucleus accumbens in rats reduced open arm duration in the elevated plus-maze (Chen et al., 2012). Likewise, $\mathrm{CRH}$ injected in the medial prefrontal cortex reduced open arm entries and duration in mice, whereas the CRHR1 antagonist, CP376395, had the opposite effect (Miguel et al., 2014). CRH injected in the medial prefrontal cortex was also anxiogenic in rats, though only at a low dose, the high dose producing an anxiolytic effect (Ohata and Shibasaki, 2011). Intra-medial prefrontal cortex infusions of $\mathrm{CRH}$ reduced open arm entries and duration regardless of whether rats were preexposed to restraint stress (Jaferi and Bhatnagar, 2007). In contrast, $\mathrm{CRH}$ administered in the Fr2 region of rat frontal cortex increased open arm entries, an anxiolytic effect blocked by alpha-helical-CRH9-41 and NBI27914 (Zieba et al., 2008).

Thus, under some conditions, $\mathrm{CRH}$ is anxiogenic in the elevated plus-maze when injected in basolateral amygdala, ventral hippocampus, lateral septum, bed nucleus of the stria terminalis, nucleus accumbens, periaqueductal grey, and medial frontal cortex, regions containing CRHR1 and CRHR2. The same effect occurred after $\mathrm{CRH}$ overexpression by a lentiviral vector in the central amygdala. In an opposite manner, anxiolytic effects were seen after $\mathrm{CRH}$ knockdown in central amygdala and CRHR antagonist injections in basolateral and central amygdala, and 
medial prefrontal cortex. As mentioned in section 2.2.1, the amygdala and hippocampus are interconnected and the subiculum projects to the nucleus accumbens (Witter and Amaral, 2004). Basolateral and central nuclei of the amygdala project to the paraventricular hypothalamus, source of $\mathrm{CRH}$-containing neurons (Gray, 1993; Gray et al., 1989). As mentioned in overview section 1, CRHcontaining neurons are also found in the bed nucleus of the stria terminalis, a major afferent region to the paraventricular hypothalamus. The anxiety-inducing effects of $\mathrm{CRH}$ in the periaqueductal grey may be explained by its afferents from amygdala, bed nucleus of the stria terminalis, and hypothalamus (Gray and Magnuson, 1992). Moreover, the periaqueductal grey receives fibers from the medial prefrontal cortex that also innervate the hypothalamus (Keay and Bandler, 2004).

\subsection{Other stress-linked peptides in hypothalamus and pituitary}

The icv injection of neuromedin S, an HPA activator (Mori et al., 2008), decreased open arm entries and duration relative to a vehicle solution (Jaszberenyi et al., 2007). Anxiogenic effects in the elevated plus-maze were also revealed after ip or $3^{\text {rd }}$ ventricle administration of ghrelin, an effect counteracted by the CRHR antagonist alpha-helical $\mathrm{CRH}-9-41$ (Asakawa et al., 2001). Ip-injected ghrelin augmented serum corticosterone levels and hypothalamic $\mathrm{CRH}$ but not urocortin mRNA expression in the hypothalamus. Ghrelin decreased open arm entries and duration in rats whether injected icv (Carlini et al., 2002) or in hippocampus but not amygdala or dorsal raphe (Carlini et al., 2004). The same decrease in open arm entries and duration occurred with ghrelin infused into arcuate, paraventricular, ventromedial, or perifornical region of lateral hypothalamus (Currie et al., 2012). Icvadministered urotensin-2 also decreased open arms entries and duration in mice (Matsumoto et al., 2004). Likewise, icv-administered obestatin decreased open arm 
duration (Szakacs et al., 2015), as did icv-infused PACAP, an effect counteracted by the CRHR antagonist, D-Phe-CRH-12-41 (Dore et al., 2013). Similarly, open arm entries were downregulated after icv-administered C-type natriuretic peptide and blocked by alpha-helical-CRH (Jahn et al., 2001). But in regard to a pituitary-like hormone, sc-administered ORG2766, the ACTH analog, in neonatal rats had no effect on open arm exploration when tested at 3 months of age (Horvath et al., 1999).

\subsection{Glucocorticoid and mineralocorticoid receptor agonists and antagonists}

\subsubsection{Intracerebroventricular and peripheral injections}

Corticosterone effects on the elevated plus-maze seem to fit within narrow dose ranges and lengths of treatment. Acute $5 \mathrm{mg} / \mathrm{kg} \mathrm{sc}$ corticosterone increased open arm entries and duration in rats (Andreatini and Leite, 1994). A higher acute dose of $20 \mathrm{mg} / \mathrm{kg}$ ip corticosterone increased open arm duration in rats even when tested one week after the injection (Wang et al., 2014). But with the same delay, a lower acute dose of $10 \mathrm{mg} / \mathrm{kg}$ sc corticosterone decreased open arm entries and duration in rats (Kim et al., 2014; Mitra and Sapolsky, 2008). The same decrease in open arm duration was found after acute $0.5 \mathrm{mg} / \mathrm{kg}$ ip corticosterone at the more usual 20 min post-injection interval in C57BL/6 mice (Espallergues et al., 2012). On the contrary, no effect occurred after acute 20 or $40 \mathrm{mg} / \mathrm{kg}$ ip corticosterone in rats (Lim et al., 2012).

There is clearer evidence regarding corticosterone-induced anxiogenesis after repeated administration. In rats, $20 \mathrm{mg} / \mathrm{kg}$ corticosterone ip for 1,2 , or 3 weeks decreased open arm duration, as did $25 \mathrm{mg} / \mathrm{kg} \mathrm{sc}$ corticosterone for 4 weeks (Pego et al., 2008) or $40 \mathrm{mg} / \mathrm{kg}$ ip for 1 or 3 weeks (Lim et al., 2012). Likewise, $40 \mathrm{mg} / \mathrm{kg} \mathrm{sc}$ corticosterone for 3 (Lee et al., 2013) or 4 (Lee et al., 2010) weeks decreased open arm duration in C57BL/6J mice. Moreover, a 3-week regimen of corticosterone in 
drinking water decreased open arm entries and duration in rats (Donner et al., 2012). Rats chronically administered via osmotic minipumps with the mineralocorticoid agonist, aldosterone, also had fewer open arm entries and duration (Hlavacova and Jezova, 2008). On the contrary, $10 \mathrm{mg} / \mathrm{kg} \mathrm{sc}$ corticosterone for 10 days had no effect on the elevated plus-maze in rats (Mitra and Sapolsky, 2008) and neither did a slowrelease pellet of corticosterone for 3 weeks in C57BL/6J mice (Demuyser et al., 2016). Thus, anxiogenesis seems evident at $20 \mathrm{mg} / \mathrm{kg}$ or higher for at least one week.

Two studies concern the effects of glucocorticoids during development. When mother rats were injected sc with dexamethasone thoughout pregnancy or only the final week of gestation, adult offspring had fewer total arm entries than vehicletreated rats only in the latter procedure (Welberg et al., 2001). But when mother rats were injected sc with corticosterone from postnatal days 30 to 45 , offspring tested on postnatal day 46 showed no change in the elevated plus-maze, and neither did corticosterone administered in the drinking water on postnatal days 30 to 45 or 70 to 85 (Waters and McCormick, 2011).

One might expect the opposite pattern of anxiolysis with glucocorticoid inhibitors or receptor antagonists, as found when acute $25 \mathrm{mg} / \mathrm{kg}$ ip metyrapone, the corticosterone synthesis inhibitor, increased open arm duration in previously footshock-stressed though not in non-stressed rats (Roozendaal et al., 1996). Likewise, acute $75 \mathrm{mg} / \mathrm{kg}$ ip metyrapone had no effect on open arm exploration in non-stressed mice (Lorivel et al., 2010). An acute icv injection of either the glucocorticoid receptor antagonist, mifepristone, or the mineralocorticoid receptor antagonist, spironolactone, prevented the decrease in open arm duration after restraint stress (Calvo and Volosin, 2001). Likewise, open arm duration increased 
after icv-injected mifepristone or spironolactone after footshock stress (Korte et al., 1995). In addition, chronic sc treatment with the mineralocorticoid receptor antagonist, eplerenone, increased open arm entries and duration (Hlavacova et al., 2010). But continuous icv administration of mifepristone for 4 days had no effect in the elevated plus-maze in non-stressed rats (Oitzl et al., 1998).

Again in line with an anxiolytic action, transgenic mice bearing a glucocorticoid receptor antisense construct had higher open arm entries and duration than wild-type (Rochford et al., 1997). Moreover, viral-mediated overexpression of a chimeric steroid receptor binding glucocorticoids but transducing them to an estrogenic effect increased open arm duration in rats (Mitra and Sapolsky, 2010). On the contrary, rats injected icv for 1 week with an 18-base end-capped phosphorothioate-protected antisense oligodeoxynucleotide directed against mineralocorticoid receptor mRNA did not differ from controls in the elevated plus-maze (Reul et al., 1997).

\subsubsection{Injections in specific brain regions}

When specific brain regions are examined (Table 4), open arm duration declined after implants in amygdala of either dexamethasone or aldosterone, agonists respectively at glucocorticoid and mineralocorticoid sites, an effect reversed by their respective antagonists, mifepristone or spironolactone (Myers and Greenwood-Van Meerveld, 2010). Open arm duration also declined after corticosterone implants in the central nucleus of the amygdala, an effect mitigated by either mifepristone or spironolactone (Myers and Greenwood-Van Meerveld, 2007). In addition, long-lasting corticosterone implants in the central nucleus of the amygdala decreased open arm entries (Shepard et al., 2000) and duration (Greenwood-Van Meerveld et al., 2001; Shepard et al., 2000), an effect attributable to increased basal levels of $\mathrm{CRH}$ mRNA (Shepard et al., 2000). Moreover, open arm 
entries and duration declined after implants in the central nucleus of the amygdala of another glucocorticoid receptor agonist, RU28362, in ovariectomized rats (Weiser et al., 2010). In an opposite manner, viral-mediated overexpression of mineralocorticoid receptors in the basolateral amygdala increased open arm entries and duration in non-stressed rats as well as open arm entries after restraint stress (Mitra et al., 2009).

When intrahippocampal effects of mifepristone and spironolactone were considered, only the latter increased open arm entries and duration, an effect eliminated in adrenalectomized rats (Bitran et al., 1998). More particularly, open arm entries increased in rats when spironolactone was infused in ventral not dorsal hippocampus or mediofrontal cortex (McEown and Treit, 2011). Likewise, corticosterone infused in the ventral hippocampus increased open arm entries in mice reactivated for fear memory in another task (Albrecht et al., 2013). Conversely, corticosterone implants for one week in infralimbic or prelimbic but not anterior cingulate cortices decreased open arm entries and duration (Croteau et al., 2017).

When brainstem regions are examined, mifepristone infused in the nucleus of the solitary tract decreased open arm entries (Ghosal et al., 2014). In an opposite manner, viral-mediated deletion of glucocorticoid receptors in the dorsal raphe increased open arm duration in non-stressed but not in mice subject to intruder stress (Vincent et al., 2014).

In summary, amygdala, hippocampus, prefrontal cortex, and nucleus of the solitary tract, and dorsal raphe appear as targets for glucocorticoid- or mineralocorticoid-mediated effects on anxiety-related behavior in the elevated plusmaze. There is evidence that agonists at both receptors in the amygdala decrease open arm exploration. The mineralocorticoid receptor at least appears relevant in the 
hippocampus as well as the glucocorticoid receptor in the dorsal raphe and the nucleus of the solitary tract. As mentioned in sections 2.2.1 and 5.1.2, the amygdala and hippocampus are anatomically interrelated. The nucleus of the solitary tract is relevant to emotion-related phenomena because it possesses abundant glucocorticoid and mineralocorticoid receptors (Herman, 1993), receives input from infralimbic cortex (Fisk and Wyss, 2000) and central amygdaloid nucleus (Saha, 2005), and projects back to these regions in addition to the bed nucleus of the stria terminalis (Saper, 2004). Widespread ascending dorsal raphe target areas include hypothalamus, basal ganglia, and neocortex (Harding et al., 2004).

\section{Elevated T-maze}

The elevated T-maze consists of one arm surrounded by three walls intersecting two open arms (Graeff et al., 1998; Pinheiro et al., 2007; Zangrossi and Graeff, 2014). Emergence latencies from the enclosed arm reflect anxiety-like behavior, whereas escape latencies from an open arm reflect panic-like behavior. As in the elevated plus-maze (see section 5), diazepam is an effective anxiolytic in the elevated T-maze (Echeverry et al., 2001; Viana et al., 1994).

\subsection{CRHR agonists and antagonists}

The anatomic basis of elevated T-maze behavior has only just begun to be mapped out (Table 5). $\mathrm{CRH}$ injected in the medial nucleus of the amygdala increased latencies before rats emerged from the enclosed arm of the elevated T-maze, whereas injection in the same brain area of the CRHR1 antagonist, antalarmin, counteracted the anxiogenic effects of $\mathrm{CRH}$ and at a higher dose decreased these latencies (Vicentini et al., 2014). Likewise, the CRHR2 agonist, urocortin-2, injected in the medial nucleus of the amygdala increased latencies before rats emerged from the enclosed arm, whereas intra-amygdala astressin 2-B, a CRHR2 antagonist, 
counteracted the anxiogenic effects of urocortin-2 and at a higher dose decreased these latencies (Alves et al., 2016).

In addition to the amygdala, $\mathrm{CRH}$ injected in the dorsomedial hypothalamus, a region involved in the cardiovascular responses to stress (Stotz-Potter et al., 1996), increased latencies before emerging from the enclosed arm, whereas antalarmin counteracted the anxiogenic effects of $\mathrm{CRH}$ and at a higher dose decreased these latencies (Silva et al., 2014). However, when injected into the periaqueductal gray, $\mathrm{CRH}$ facilitated escape not avoidance responses, a panicogenic effect, whereas urocortin-2 caused the reverse effect (Sergio et al., 2014). These results indicate that although $\mathrm{CRH}$ has anxiogenic properties in amygdala and dorsomedial hypothalamus, it may also cause panic-like responses in the periaqueductal gray.

\subsection{Glucocorticoids and mineralocorticoids}

Corticosterone administration in the drinking water for 21 days increased avoidance latencies without affecting escape latencies in the elevated T-maze (Fan et al., 2014). Likewise, a slow-release corticosterone pellet for 21 days increased avoidance latencies without affecting escape latencies (Diniz et al., 2011). Unexpectedly, the glucocorticoid receptor antagonist, mifepristone, or the mineralocorticoid receptor antagonist, spironolactone, injected sc for 21 days also increased avoidance latencies without affecting escape latencies (Fan et al., 2014).

\section{Emergence from a small compartment and defensive withdrawal}

In emergence and defensive withdrawal tests, a small compartment is inserted inside a larger one. In the emergence test, animals are placed inside the small compartment and the time taken before emerging with four paws towards the larger one is measured (Lalonde and Strazielle, 2008; Paré et al., 2001). The emergence test is over as soon as the animal exits the small compartment. Each compartment 
may be either familiar or novel to the animal. The smaller compartment may be its home-cage with cage-mates removed. In the defensive withdrawal test, beside emergence latencies, entries and time spent in each compartment are measured. The defensive withdrawal test continues until a specific cut-off time is reached while the animal re-enters and vacates each compartment at will.

Relative to the non-stress condition, restraint stress increased latencies before emerging from the small chamber as well as the time spent in it (Smagin et al., 1996). In an opposite manner, chlordiazepoxide decreased emergence latencies and time spent in the small compartment (He et al., 2000; Lalonde and Strazielle, 2010; Yang et al., 1990). Likewise, diazepam (Paré et al., 2001) and alprazolam (Lelas et al., 2004) reduced emergence latencies from the small chamber.

\subsection{CRHR agonists and antagonists}

\subsubsection{Intracerebroventricular and peripheral injections}

In contrast to benzodiazepines, icv-administered $\mathrm{CRH}$ increased emergence latencies as well as exits from and time spent inside the small compartment (Spina et al., 2002; Ward et al., 1998; Yang and Dunn, 1990; Yang et al., 1990). As expected from the poor brain penetration of $\mathrm{CRH}$, emergence latencies increased only after icv, not ip, injections (Takahashi et al., 1989). No such anxiogenic action occurred after icv-injected urocortin-1, the CRHR2 agonist (Spina et al., 2002). An expected finding is that Crhbp null mutant mice lacking $\mathrm{CRH}$ binding protein had fewer exits from the small to the large chamber and did not differ in latencies to first exit (Karolyi et al., 1999).

In an opposite manner to $\mathrm{CRH}$, anxiolytic-like effects have been obtained with CRHR antagonists. In particular, emergence latencies decreased after icv-injected alpha-helical-CRH-9-41 (Takahashi et al., 1989). This treatment reduced both 
emergence latencies and time spent in the small compartment (Rodriguez de Fonseca et al., 1996) as well as reversing restraint stress-induced increases in emergence latencies and time spent in the small compartment (Yang et al., 1990). The same pattern was discerned with selective CRHR1 antagonists, since ip-injected antalarmin decreased emergence latencies and time spent in the small compartment (Zorrilla et al., 2002) and chronic treatment with the same drug via osmotic minipumps increased time spent in the large compartment (Arborelius et al., 2000). Moreover, po-administered DMP904 reduced emergence latencies (He et al., 2000; Lelas et al., 2004) while po-administered R121919 reduced emergence latencies and time spent in the small chamber (Heinrichs et al., 2002). In another study, R121919 administered via osmotic minipumps increased time spent in the large compartment but without affecting emergence latencies (Gutman et al., 2011). Concordant with the anxiolytic-like pattern of CRHR1 blockade is the finding that Crhr1 null mutant mice emerged more quickly compared with wild-type and spent a longer time outside the small compartment (Smith et al., 1998). In addition, chronic icv-administered antisense $\mathrm{CRHR} 1$ but not $\mathrm{CRHR} 2$ oligonucleotides decreased emergence latencies and time spent in the small compartment (Heinrichs et al., 1997). Yet the influence of CRHR2 cannot yet be excluded, because time spent in the large compartment increased after icv administration of the CRHR2 antagonist, anti-sauvagine-30 (Takahashi et al., 2001).

\subsubsection{Injections in specific brain regions}

The anatomical basis of $\mathrm{CRH}$-mediated effects on emergence and defensive withdrawal tests has rarely been examined (Table 6). A lentivirus containing a $\mathrm{CRH}$ specific promoter used to overexpress $\mathrm{CRH}$ in the bed nucleus of the stria terminalis for 14 days had no effect (Sink et al., 2013b). However, time spent inside the small 
chamber of the defensive withdrawal test increased when $\mathrm{CRH}$ was injected in the locus coeruleus (Butler et al., 1990). In an opposite manner, alpha-helical CRH-9-41 infusion in the locus coeruleus prior to restraint stress decreased time spent in the small chamber (Smagin et al., 1996). Arborelius et al. (2000) hypothesized that $\mathrm{CRH}$ neurons in Barrington's nucleus that project to the locus coeruleus (Aston-Jones, 2004; Valentino et al., 1996) are responsible for opposing effects of CRHR agonists and antagonists on anxiety. Conversely, noradrenergic afferents may contact $\mathrm{CRH}-$ containing neurons in several forebrain structures (Gray, 1993). As proposed by Stone et al. (2011), the ventral noradrenergic bundle includes afferents from the lateral tegmental noradrenergic nuclei $(\mathrm{A} 1$ and $\mathrm{A} 2)$ to $\mathrm{CRH}$-containing neurons in paraventricular hypothalamus, bed nucleus of the stria terminalis, and central nucleus of the amygdala and may activate these neurons by stimulating $\alpha 1$ - or $\beta$ adrenoceptors.

\subsection{Glucocorticoids and mineralocorticoids}

Corticosterone administration in the drinking water for 17 days increased emergence latencies from the small compartment, though no effect occured after 1 day (Ardayfio and Kim, 2006).

\section{Light-dark box}

In the light-dark box test, entries and duration as well as latencies before first entry in the lit compartment reflect photophobic tendencies of nocturnal animals (Crawley, 1981; Hascoët et al., 2001; Misslin et al., 1989). As in other anxiety tests, diazepam has an anxiolytic action in the light-dark box test, as demonstrated by increases in time spent inside the lit compartment (Bhatt et al., 2013; Crawley, 1981;

Onaivi and Martin, 1989). As in other anxiety tests, mouse strain differences have been noted (Kulesskaya and Voikar, 2014). 


\section{1 $\mathrm{CRH}$ receptor agonists and antagonists}

Unlike diazepam, icv-administered urocortin-1 reduced entries and duration in the lit part of the light-dark box in mice (Moreau et al., 1997). The limbic system appears important in this test, because lentivirus-mediated $\mathrm{CRH}$ overexpression in the central nucleus amygdala of mice after 3-day induction by doxycycline in the drinking water decreased entries in the lit chamber following restraint stress (Regev et al., 2012). However, the same manipulation after 4-month administration increased entries in the lit zone with or without restraint stress as well as increasing time spent in the lit zone after restraint stress, an overcompensatory response whose mechanism remains to be determined (Regev et al., 2011). No effect occurred in the bed nucleus of the stria terminalis. As expected from genetic manipulations in other paradigms, Crh transgenic mice overexpressing the rat version of the gene had higher latencies before entering and spent less time in the lit portion of the box (van Gaalen et al., 2002). Likewise, conditional Crh transgenic mice overexpressing the rat version of the gene in neocortex and hippocampus but not hypothalamus had fewer entries in the lit portion (Vicentini et al., 2009).

Neither ip-injected SSR125543A nor antalarmin, CRHR1 antagonists, had any effect on mouse behavior in the light-dark box (Griebel et al., 2002). But, as expected, Crhr1 null mutant mice lacking CRHR1 had more entries, longer durations, and shorter latencies to enter the lit compartment (Timpl et al., 1998), as did conditional Crhr1 null mutant mice lacking CRHR1 specifically in the limbic system (Müller et al., 2003). The basal ganglia also appears involved because knockdown of CRHR1 mRNA by a lentiviral-based system in the mouse lateral globus pallidus decreased entries and time spent in the lit zone (Sztainberg et al., 2011). 
Results are mixed regarding CRHR2. Indeed, icv-administered urocortin-3, the CRHR2 agonist, decreased latencies before first entry in the lit area, an anxiolytic effect (Venihaki et al., 2004). In contrast, entries and duration in the lit chamber decreased after icv-administered CRHR2 antisense oligonucleotides compared with vehicle- or scrambled oligonucleotide-treated groups (Isogawa et al., 2003). Although one Crhr2 null mutant model showed less time spent in the lit part (Kishimoto et al., 2000), no effect occurred with a different Crhr2 null mutant model (Bale et al., 2000).

\subsection{Glucocorticoids and mineralocorticoids}

Long-lasting corticosterone implants for 4 to 16 days reduced time spent in the lit chamber, but acute $40 \mathrm{mg} / \mathrm{kg}$ ip corticosterone had no effect (Murray et al., 2008). However, icv-injected urotensin-2 reduced entries in the lit chamber (do-Rego et al., 2005). The limbic system appears involved, because intrahippocampal injections of sprironolactone, the mineralocorticoid receptor antagonist, increased time spent in the lit chamber (Smythe et al., 1997).

\section{Brain regions and $\mathrm{CRH}$-mediated anxiety}

\subsection{Elevated plus-maze and elevated T-maze tests}

The anatomic basis of $\mathrm{CRH}$-mediated anxiety has advanced in regard to elevated plus-maze and elevated T-maze tests (Tables 3 and 5 ). In the elevated plus-maze, $\mathrm{CRH}$ caused anxiogenesis when infused in basolateral amygdala, ventral hippocampus, lateral septum, bed nucleus of the stria terminalis, nucleus accumbens, periaqueductal grey, and medial frontal cortex. Moreover, a lentiviral vector overexpressing $\mathrm{CRH}$ in the central nucleus of the amygdala was anxiogenic in the same maze. In the elevated T-maze, $\mathrm{CRH}$ was anxiogenic when infused in amygdala and dorsomedial hypothalamus. Thus, the amygdala appears as a 
common target of $\mathrm{CRH}$-induced anxiogenesis in both tests. Further research must identify the precise neural circuits underlying both tests.

\subsection{Elevated plus-maze and open-field tests}

The anatomic basis of $\mathrm{CRH}$-mediated anxiety has advanced in regard to elevated plus-maze and open-field tests (Tables 2 and 5). In the center zone of the open-field, $\mathrm{CRH}$ caused anxiogenesis when infused in hippocampus and shell region of the nucleus accumbens. In an opposite manner, chronic lentivirus-induced $\mathrm{CRH}$ overexpression in the central nucleus of the amygdala increased center region entries, a sign of anxiolysis, which may have been the result of receptor hyposensitivity. Decreases in center zone entries and duration occurred after infusion of a CHRHR2 agonist in the lateral septum but increases in center zone entries occurred after infusion of a CRHR1 antagonist in the lateral globus pallidus.

When considering that anxiogenesis occurred after $\mathrm{CRH}$ infusion in basolateral amygdala, ventral hippocampus, lateral septum, bed nucleus of the stria terminalis, nucleus accumbens, periaqueductal grey, and medial frontal cortex in the elevated plus-maze, the hippocampus and nucleus accumbens appear as common targets of $\mathrm{CRH}$-induced anxiogenesis in both tests. Because the subiculum projects to the nucleus accumbens (Witter and Amaral, 2004), these two regions may form part of the the neural circuits underlying both tests. One can see the work remaining to be done in understanding neuroanatomical pathways of exploratory activity when more than one test is considered.

\section{References}

Adamec, R.E. and McKay, D. (1993). The effects of CRF and alpha-helical CRF on anxiety in normal and hypophysectomized rats. J. Psychopharmacol. 7, 346354. 
Adamec, R.E., Sayin, U., and Brown, A. (1991). The effects of corticotrophin releasing factor (CRF) and handling stress on behavior in the elevated plusmaze test of anxiety. J. Psychopharmacol. 5, 175-186.

Albertin, G., Casale, V., Ziolkowska, A., Spinazzi, R., Malendowicz, L.K., Rossi, G.P., and Nussdorfer, G.G. (2006). Urotensin-II and Ull-receptor expression and function in the rat adrenal cortex. Int. J. Mol. Med. 17, 1111-1115.

Albrecht, A., Çalışkan, G., Oitzl, M.S., Heinemann U., and Stork, O. (2013). Longlasting increase of corticosterone after fear memory reactivation: anxiolytic effects and network activity modulation in the ventral hippocampus. Neuropsychopharmacology 38, 386-394.

Al Chawaf, A., Xu, K., Tan, L., Vaccarino, F.J., Lovejoy, D.A., and Rotzinger, S. (2007). Corticotropin-releasing factor (CRF)-induced behaviors are modulated by intravenous administration of teneurin C-terminal associated peptide- 1 (TCAP-1). Peptides 28, 1406-1415.

Allen, B.D., Sutanto, W., and Jones, M.T. (1988). A correlative study of RU38486 biopotency and competition with $[3 \mathrm{H}]$ dexamethasone for receptors in the rat central nervous system. J. Steroid Biochem. 30, 411-415.

Alves, S.W., Portela, N.C., Silva, M.S., Céspedes, I.C., Bittencourt, J.C., and Viana, M.B. (2016). The activation and blockage of CRF type 2 receptors of the medial amygdala alter elevated T-maze inhibitory avoidance, an anxiety-related response. Behav. Brain Res. 305, 191-197.

Andreatini, R. and Leite, J.R. (1994). Evidence against the involvement of ACTH/CRF release or corticosteroid receptors in the anxiolytic effect of corticosterone. Braz. J. Med. Biol. Res. 27, 1237-1241. 
Appenrodt, E., Kröning, G., and Schwarzberg, H. (1999). Increased plasma ACTH in rats exposed to the elevated plus-maze is independent of the pineal gland. Psychoneuroendocrinology 24, 833-838.

Arborelius, L., Skelton, K.H., Thrivikraman, K.V., Plotsky, P.M., Schulz, D.W., and Owens, M.J. (2000). Chronic administration of the selective corticotropinreleasing factor 1 receptor antagonist CP-154,526: behavioral, endocrine and neurochemical effects in the rat. J. Pharmacol. Exp. Ther. 294, 588-597.

Ardayfio, P. and Kim, K. (2006). Anxiogenic-like effect of chronic corticosterone in the light-dark emergence task in mice. Behav. Neurosci. 120, 249-256. Not in text

Asakawa, A., Inui, A., Kaga, T., Yuzuriha, H., Nagata, T., Fujimiya, M., Katsuura, G., Makino, S., Fujino, M.A., and Kasuga, M. (2001). A role of ghrelin in neuroendocrine and behavioral responses to stress in mice. Neuroendocrinology $74,143-147$.

Aston-Jones, G. (2004). Locus coeruleus, A5 and A7 noradrenergic cell groups. In: G. Paxinos, ed. The rat nervous system, 3rd ed. (Amsterdam: Elsevier), pp. 259-294.

Bakke, H.K., Bogsnes, A., and Murison, R. (1990). Studies on the interaction between ICV effects of CRF and CNS noradrenaline depletion. Physiol. Behav. $47,1253-1260$.

Bakshi, V.P., Newman, S.M., Smith-Roe, S., Jochman, K.A., and Kalin, N.H. (2007). Stimulation of lateral septum CRF2 receptors promotes anorexia and stress-like behaviors: functional homology to CRF1 receptors in basolateral amygdala. J. Neurosci. 27, 10568-10577. 
Baldwin, H.A., Rassnick, S., Rivier, J., Koob, G.F., and Britton, K.T. (1991). CRF antagonist reverses the "anxiogenic" response to ethanol withdrawal in the rat. Psychopharmacology 103, 227-232.

Bale, T.L., Contarino, A., Smith, G.W., Chan, R., Gold, L.H., Sawchenko, P.E., Koob, G.F., Vale, W.W., and Lee, K.F. (2000). Mice deficient for corticotropinreleasing hormone receptor-2 display anxiety-like behaviour and are hypersensitive to stress. Nat. Genet. 24, 410-414.

Belzung, C. and Griebel, G. (2001). Measuring normal and pathological anxiety-like behaviour in mice: a review. Behav. Brain Res. 125, 141-149.

Berridge, C.W. and Dunn, A.J. (1989). CRF and restraint-stress decrease exploratory behavior in hypophysectomized mice. Pharmacol. Biochem. Behav. 34, 517519.

Berridge, C.W. and Dunn, A.J. (1987). A corticotropin-releasing factor antagonist reverses the stress-induced changes of exploratory behavior in mice. Horm. Behav. 21, 393-401.

Beuving, G. and Vonder, G.M. (1977). Daily rhythm of corticosterone in laying hens and the influence of egg laying. J. Reprod. Fertil. 51, 169-173.

Bhatt, S., Mahesh, R., Devadoss, T., and Jindal, A. (2013). Anxiolytic-like effect of Nn-butyl-3-methoxyquinoxaline-2-carboxamide (60) in experimental mouse models of anxiety. Indian J. Exp. Biol. 51, 510-514.

Bilkei-Gorzo, A. and Gyertyan, I. (1996). Some doubts about the basic concept of hole-board test. Neurobiology (Bp) 4, 405-415.

Bittencourt, J.C., Vaughan, J., Arias, C., Rissman, R.A., Vale, W.W., and Sawchenko, P.E. (1999). Urocortin expression in rat brain: evidence against a 
pervasive relationship of urocortin-containing projections with targets bearing type 2 CRF receptors. J. Comp. Neurol. 415, 285-312.

Bitran, D., Shiekh, M., Dowd, J.A., Dugan, M.M., and Renda, P. (1998). Corticosterone is permissive to the anxiolytic effect that results from the blockade of hippocampal mineralocorticoid receptors. Pharmacol. Biochem. Behav. 60, 879-887.

Bohlen, M., Hayes, E.R., Bohlen, B., Bailoo, J.D., Crabbe, J.C., and Wahlsten, D. (2014). Experimenter effects on behavioral test scores of eight inbred mouse strains under the influence of ethanol. Behav. Brain Res. 272, 46-54.

Borelli, K.G. and Brandao, M.L. (2008). Effects of ovine CRF injections into the dorsomedial, dorsolateral and lateral columns of the periaqueductal gray: a functional role for the dorsomedial column. Horm. Behav. 53, 40-50.

Bourin, M. (2015). Animal models for screening anxiolytic-like drugs: a perspective. Dialogues Clin. Neurosci. 17, 295-303.

Bourin, M. and Hascoët, M. (2003). The mouse light/dark box test. Eur. J. Pharmacol. $463,55-65$.

Britton, D.R., Koob, G.F., Rivier, J., and Vale, W. (1982). Intraventricular corticotropin-releasing factor enhances behavioral effects of novelty. Life Sci. 31, 363-367.

Britton, K.T., Lee, G., Vale, W., Rivier, J., and Koob, G.F. (1986). Corticotropin releasing factor (CRF) receptor antagonist blocks activating and 'anxiogenic' actions of CRF in the rat. Brain Res. 369, 303-306.

Brown, G.R. and Nemes, C. (2008). The exploratory behaviour of rats in the holeboard apparatus: is head-dipping a valid measure of neophilia? Behav. Proc. $78,442-448$ 
Bruchas, M.R., Land, B.B., Lemos, J.C., and Chavkin, C. (2009). CRF1-R activation of the dynorphin/kappa opioid system in the mouse basolateral amygdala mediates anxiety-like behavior. PLoS One 4(12), e8528.

Brummelte, S., Pawluski, J.L., and Galea, L.A. (2006). High post-partum levels of corticosterone given to dams influence postnatal hippocampal cell proliferation and behavior of offspring: A model of post-partum stress and possible depression. Horm. Behav. 50, 370-382.

Butler, P.D., Weiss, J.M., Stout, J.C., and Nemeroff, C.B. (1990). Corticotropinreleasing factor produces fear-enhancing and behavioral activating effects following infusion into the locus coeruleus. J. Neurosci. 10, 176-183.

Buwalda, B., de Boer, S.F., Van Kalkeren, A.A., and Koolhaas, J.M. (1997). Physiological and behavioral effects of chronic intracerebroventricular infusion of corticotropin-releasing factor in the rat. Psychoneuroendocrinology 22, 297309.

Calabrese, E.J. (2008). An assessment of anxiolytic drug screening tests: hormetic dose responses predominate. Crit. Rev. Toxicol. 38, 489-542.

Caldji, C., Francis, D., Sharma, S., Plotsky, P. M., and Meaney, M.J. (2000). The effects of early rearing environment on the development of GABAA and central benzodiazepine receptor levels and novelty-induced fearfulness in the rat. Neuropsychopharmacology 22, 219-229.

Calfa, G., Bussolino, D., and Molina, V.A. (2007). Involvement of the lateral septum and the ventral Hippocampus in the emotional sequelae induced by social defeat: role of glucocorticoid receptors. Behav. Brain Res. 181, 23-34. 
Calfa, G., Volosin, M., and Molina, V.A. (2006). Glucocorticoid receptors in lateral septum are involved in the modulation of the emotional sequelae induced by social defeat. Behav. Brain Res. 172, 324-332.

Callahan, L.B., Tschetter, K.E., and Ronan, P.J. (2013). Inhibition of corticotropin releasing factor expression in the central nucleus of the amygdala attenuates stress-induced behavioral and endocrine responses. Front. Neurosci. 7, 195.

Campbell, B.M., Morrison, J.L., Walker, E.L., and Merchant, K.M. (2004). Differential regulation of behavioral, genomic, and neuroendocrine responses by CRF infusions in rats. Pharmacol. Biochem. Behav. 77, 447-455.

Campos, A.C., Fogaça, M.V., Aguiar, D.C., and Guimarães, F.S. (2013). Animal models of anxiety disorders and stress. Rev. Bras. Psiquiatr. 35 Suppl 2, S101111.

Canini, F., Brahimi, S., Drouet, J.B., Michel, V., Alonso, A., Buguet, A., and Cespuglio, R. (2009). Metyrapone decreases locomotion acutely. Neurosci. Lett. $457,41-44$.

Calvo, N. and Volosin, M. (2001). Glucocorticoid and mineralocorticoid receptors are involved in the facilitation of anxiety-like response induced by restraint. Neuroendocrinology 73, 261-271.

Canny, B.J., Funder, J.W., and Clarke, I.J. (1989). Glucocorticoids regulate ovine hypophysial portal levels of corticotropin-releasing factor and arginine vasopressin in a stress-specific manner. Endocrinology 125, 2532-2539.

Canteras, N.S., Simerly, R.B., and Swanson, L.W. (1995). Organization of projections from the medial nucleus of the amygdala: a PHAL study in the rat, J. Comp. Neurol. 360, 213-245. 
Cardinali, D.P. and Gómez, E. (1977). Changes in hypothalamic noradrenaline, dopamine and serotonin uptake after oestradiol administration to rats. J. Endocrinol. 73, 181-182.

Carlini, V.P., Varas, M.M., Cragnolini, A.B., Schiöth, H.B., Scimonelli, T.N., and de Barioglio, S.R. (2004). Differential role of the hippocampus, amygdala, and dorsal raphe nucleus in regulating feeding, memory, and anxiety-like behavioral responses to ghrelin. Biochem. Biophys. Res. Commun. 313, 635-641.

Carlini, V.P., Monzón, M.E., Varas, M.M., Cragnolini, A.B., Schiöth, H.B., Scimonelli, T.N., and de Barioglio, S.R. (2002). Ghrelin increases anxiety-like behavior and memory retention in rats. Biochem. Biophys. Res. Commun. 299, 739-743.

Carola, V., D'Olimpio, F., Brunamonti, E., Mangia, F, and Renzi, P. (2002). Evaluation of the elevated plus-maze and open-field tests for the assessment of anxiety-related behaviour in inbred mice. Behav. Brain Res. 134, 49-57.

Chaki, S., Nakazato, A., Kennis, L., Nakamura, M., Mackie, C., Sugiura, M., Vinken, P., Ashton, D., Langlois, X., and Steckler, T. (2004). Anxiolytic- and antidepressant-like profile of a new CRF1 receptor antagonist, R278995/CRA0450. Eur. J. Pharmacol. 485, 145-158.

Chalmers, D.T., Lovenberg, T.W., and De Souza, E.B. (1995). Localization of novel corticotropin-releasing factor receptor (CRF2) mRNA expression to specific subcortical nuclei in rat brain: comparison with CRF1 receptor mRNA expression. J. Neurosci. 15, 6340-6350.

Champagne, D., Beaulieu, J., and Drolet, G. (1998). CRFergic innervation of the paraventricular nucleus of the rat hypothalamus: a tract-tracing study. J. Neuroendocrinol. 10, 119-131. 
Chanoine, J.P., De Waele, K., and Walia, P. (2009). Ghrelin and the growth hormone secretagogue receptor in growth and development. Int. J. Obes. 33 Supp/ 1, S48-52.

Chen, Y., Brunson, K.L., Müller, M.B., Cariaga, W., and Baram, T.Z. (2000). Immunocytochemical distribution of corticotropin-releasing hormone receptor type-1 (CRF(1))-like immunoreactivity in the mouse brain: light microscopy analysis using an antibody directed against the C-terminus. J. Comp. Neurol. 420, 305-323.

Chen, Y.W., Rada, P.V., Bützler, B.P., Leibowitz, S.F., and Hoebel, B.G. (2012). Corticotropin-releasing factor in the nucleus accumbens shell induces swim depression, anxiety, and anhedonia along with changes in local dopamine/acetylcholine balance. Neuroscience 206, 155-166.

Choleris, E., Thomas, A.W., Kavaliers, M., and Prato, F.S. (2001). A detailed ethological analysis of the mouse open field test: effects of diazepam, chlordiazepoxide and an extremely low frequency pulsed magnetic field. Neurosci. Biobehav. Rev. 25, 235-260.

Cipriano, A.C., Gomes, K.S., and Nunes-de-Souza, R.L. (2016). CRF receptor type 1 (but not type 2) located within the amygdala plays a role in the modulation of anxiety in mice exposed to the elevated plus maze. Horm. Behav. 81, 59-67.

Contarino, A., Dellu, F., Koob, G.F., Smith, G.W., Lee, K.F., Vale, W., and Gold, L.H. (1999). Reduced anxiety-like and cognitive performance in mice lacking the corticotropin-releasing factor receptor 1. Brain Res. 835, 1-9.

Conti, L.H., Costello, D.G., Martin, L.A., White, M.F., and Abreu, M.E. (1994). Mouse strain differences in the behavioral effects of corticotropin-releasing factor 
(CRF) and the CRF antagonist alpha-helical CRF9-41. Pharmacol. Biochem. Behav. 48, 497-503.

Coste, S.C., Kesterson, R.A., Heldwein, K.A., Stevens, S.L., Heard, A.D., Hollis, J.H., Murray, S.E., Hill, J.K., Pantely, G.A., Hohimer, A.R., Hatton, D.C., Phillips, T.J., Finn, D.A., Low, M.J., Rittenberg, M.B., Stenzel, P., and Stenzel-Poore, M.P. (2000). Abnormal adaptations to stress and impaired cardiovascular function in mice lacking corticotropin-releasing hormone receptor-2. Nat. Genet. 24, 403409.

Crabbe, J.C., Wahlsten, D., and Dudek, B.C. (1999). Genetics of mouse behavior: interactions with laboratory environment. Science 284, 1670-1672.

Crawley, J.N. (1981). Neuropharmacologic specificity of a simple animal model for the behavioral actions of benzodiazepines. Pharmacol. Biochem. Behav. 15, 695-699.

Crawley, J.N. (1985). Exploratory behavior models of anxiety in mice. Neurosci. Biobehav. Rev. 9, 37-44.

Croteau, J.D., Schulkin, J., and Shepard, J.D. (2017). Behavioral effects of chronically elevated corticosterone in subregions of the medial prefrontal cortex. Behav. Brain Res. 316, 82-86.

Currie, P.J., Khelemsky, R., Rigsbee, E.M., Dono, L.M., Coiro, C.D., Chapman, C.D., and Hinchcliff, K. (2012). Ghrelin is an orexigenic peptide and elicits anxiety-like behaviors following administration into discrete regions of the hypothalamus. Behav. Brain Res. 226, 96-105.

Daniels, W.M., Richter, L., and Stein, D.J. (2004). The effects of repeated intraamygdala CRF injections on rat behavior and HPA axis function after stress. Metab. Brain Dis. 19, 15-23. 
David, D.J., Samuels, B.A., Rainer, Q., Wang, J.W., Marsteller, I. Mendez, I., Drew, M, Craig, D.A., Guiard, B.P., Guilloux, J.P., Artymyshyn, R.P., Gardier, A.M., Gerald, C., Antonijevic, I.A., Leonardo, E.D., and Hen, R. (2009). Neurogenesisdependent and -independent effects of fluoxetine in an animal model of anxiety/depression, Neuron 62, 479-493.

Dawson, G.R. and Tricklebank, M.D. (1995). Use of the elevated plus maze in the search for novel anxiolytic agents. Trends Pharmacol. Sci. 16, 33-36.

De Kloet, E.R. (1991). Brain corticosteroid receptor balance and homeostatic control. Front. Neuroendocrinol. 12, 95-164.

Demuyser, T., Deneyer, L., Bentea, E., Albertini, G., Van Liefferinge, J., Merckx, E., De Prins, A., De Bundel, D., Massie, A., and Smolders, I. (2016). In-depth behavioral characterization of the corticosterone mouse model and the critical involvement of housing conditions. Physiol. Behav. 156, 199-207.

Dickinson, S.L., Kennett, G.A., and Curzon, G. (1985). Reduced-5hydroxytryptamine-dependent behavior in rats following chronic corticosterone treatment. Brain Res. 345, 10-18.

Diniz, L., Dos Reis, B.B., de Castro, G.M., Medalha, C.C., and Viana, M.B. (2011). Effects of chronic corticosterone and imipramine administration on panic and anxiety-related responses. Braz. J. Med. Biol. Res. 44, 1048-1053.

Donaldson, C., Sutton, S., Perrin, M., Corrigan, A., Lewis, K., Rivier, J., Vaughan, J., and Vale, W. (1996). Cloning and characterization of human urocortin. Endocrinology 137, 2167-2170.

Donner, N.C., Montoya, C.D., Lukkes, J.L., and Lowry, C.A. (2012). Chronic noninvasive corticosterone administration abolishes the diurnal pattern of tph2 expression. Psychoneuroendocrinology 37, 645-661. 
Dore, R., lemolo, A., Smith, K.L., Wang, X., Cottone, P., and Sabino, V. (2013). CRF mediates the anxiogenic and anti-rewarding, but not the anorectic effects of PACAP. Neuropsychopharmacology 38, 2160-2169.

do-Rego, J.C., Viana, A.F., Le Maître, E., Deniel, A., Rates, S.M., Leroux-Nicollet, I., and Costentin, J. (2006). Comparisons between anxiety tests for selection of anxious and non anxious mice. Behav. Brain Res. 169, 282-288.

do-Rego, J.C., Chatenet, D., Orta, M.H., Naudin, B., Le Cudennec, C., Leprince, J., Scalbert, E., Vaudry, H., and Costentin, J. (2005). Behavioral effects of urotensin-II centrally administered in mice. Psychopharmacology 183, 103-117.

Dunn, A.J. and Berridge, C.W. (1987). Corticotropin-releasing factor administration elicits a stress-like activation of cerebral catecholaminergic systems. Pharmacol. Biochem. Behav. 27, 685-691.

Dunn, A.J. and Berridge, C.W. (1990). Physiological and behavioral responses to corticotropin-releasing factor administration: is CRF a mediator of anxiety or stress responses? Brain Res. Rev. 15, 71-100.

Dunn, A.J. and Swiergiel, A.H. (1999). Behavioral responses to stress are intact in CRF-deficient mice. Brain Res. 845, 14-20.

Durcan, M.J., Lister, R.G., Eckardt, M.J., and Linnoila, M. (1988). Interactions of 5HT reuptake inhibitors and ethanol in tests of exploration and anxiety. Adv. Alcohol Subst. Abuse 7, 113-117.

Eaves, M., Thatcher-Britton, K., Rivier, J., Vale, W., and Koob, G.F. (1985). Effects of corticotropin releasing factor on locomotor activity in hypophysectomized rats. Peptides 6, 923-926. 
Echeverry, M.B., Hasenöhrl, R.U., Huston, J.P., and Tomaz, C. (2001). Comparison of neurokinin SP with diazepam in effects on memory and fear parameters in the elevated T-maze free exploration paradigm. Peptides 22, 1031-1036.

Ennaceur, A. and Chazot, P.L. (2016). Preclinical animal anxiety research - flaws and prejudices. Pharmacol. Res. Perspect. 4(2), e00223.

Espallergues, J., Teegarden, S., Veerakumar, A., Boulden, J., Challis, C., Jochems, J., Chan, M., Petersen, T., Deneris, E., Matthias, P., Hahn, C., Lucki, I., Beck, S., and Berton, O. (2012). HDAC6 regulates glucocorticoid receptor signaling in serotonin pathways with critical impact on stress resilience. J. Neurosci. 32, 4440-4416.

Etches, R.J. (1976). A radioimmunoassay for corticosterone and its application to the measurement of stress in poultry. Steroids $28,763-773$.

Fan, Y., Chen, P., Li, Y., Cui, K., Noel, D.M., Cummins, E.D., Peterson, D.J., Brown, R.W., and Zhu, M.Y. (2014). Corticosterone administration up-regulated expression of norepinephrine transporter and dopamine $\beta$-hydroxylase in rat locus coeruleus and its terminal regions. J. Neurochem. 128, 445-458.

Fatima, A., Haroon, M.F., Wolf, G., Engelmann, M., and Spina, M.G. (2010). Urocortin 1 administered into the hypothalamic supraoptic nucleus affects openfield behaviour in rats. Amino Acids 38, 1407-1414.

Felszeghy, K., Sasvári, M., and Nyakas, C. (1993). Behavioral depression: opposite effects of neonatal dexamethasone and ACTH-(4-9) analogue (ORG 2766) treatments in the rat. Horm. Behav. 27, 380-396.

Ferguson, S.A. and Holson, R.R. (1999). Neonatal dexamethasone on day 7 causes mild hyperactivity and cerebellar stunting. Neurotoxicol. Teratol. 21, 71-76. 
Fernandes, C. and File, S.E. (1996). The influence of open arm ledges and maze experience in the elevated plus-maze. Pharmacol. Biochem. Behav. 54, 31-40.

Farrokhi, C.B., Tovote, P., Blanchard, R.J., Blanchard, D.C., Litvin, Y., and Spiess, J. (2007). Cortagine: behavioral and autonomic function of the selective CRF receptor subtype 1 agonist. CNS Drug Rev. 13, 423-443.

File, S.E. (2001). Factors controlling measures of anxiety and responses to novelty in the mouse. Behav. Brain Res. 125, 151-157.

File, S.E. (1982). The rat corticosterone response: habituation and modification by chlordiazepoxide. Physiol. Behav. 29, 91-95.

File, S.E. and Wardill, A.G. (1975). Validity of head-dipping as a measure of exploration in a modified hole-board. Psychopharmacologia 44, 53-59.

File, S.E., Zangrossi, H. Jr, Sanders, F.L., and Mabbutt, P.S. (1994). Raised corticosterone in the rat after exposure to the elevated plus-maze. Psychopharmacology 113, 543-546.

Fisk, G.D. and Wyss, J.M. (2000). Descending projections of infralimbic cortex that mediate stimulation-evoked changes in arterial pressure. Brain Res. 859, 83-95.

Forray, M.I. and Gysling, K. (2004). Role of noradrenergic projections to the bed nucleus of the stria terminalis in the regulation of the hypothalamic-pituitaryadrenal axis. Brain Res. Rev. 47, 145-160.

Fuxe, K., Wikström, A.C., Okret, S., Agnati, L.F., Härfstrand, A., Yu, Z.Y., Granholm, L., Zoli, M., Vale, W., and Gustafsson, J.A. (1985). Mapping of glucocorticoid receptor immunoreactive neurons in the rat tel- and diencephalon using a monoclonal antibody against rat liver glucocorticoid receptor. Endocrinology 117, 1803-1812. 
Gammie, S.C. and Stevenson, S.A. (2006). Intermale aggression in corticotropinreleasing factor receptor 1 deficient mice. Behav. Brain Res. 171, 63-69.

Gammie, S.C., Bethea, E.D., and Stevenson, S.A. (2007). Altered maternal profiles in corticotropin-releasing factor receptor 1 deficient mice. BMC Neurosci. 8, 17.

Ghosal, S., Bundzikova-Osacka, J., Dolgas, C.M., Myers, B., and Herman, J.P. (2014). Glucocorticoid receptors in the nucleus of the solitary tract (NTS) decrease endocrine and behavioral stress responses. Psychoneuroendocrinology 45, 142-153.

Gomez-Sanchez, E. and Gomez-Sanchez, C.E. (2014). The multifaceted mineralocorticoid receptor. Compr. Physiol. 4, 965-994.

Graeff, F.G., Netto, C.F., and Zangrossi, H. Jr. (1998). The elevated T-maze as an experimental model of anxiety. Neurosci. Biobehav. Rev. 23, 237-246.

Gray, J.M., Vecchiarelli, H.A., Morena, M., Lee, T.T., Hermanson, D.J., Kim, A.B., McLaughlin, R.J., Hassan, K.I., Kühne, C., Wotjak, C.T., Deussing, J.M., Patel, S., and Hill, M.N. (2015). Corticotropin-releasing hormone drives anandamide hydrolysis in the amygdala to promote anxiety. J. Neurosci. 35, 3879-3892.

Gray, T.S. (1993). Amygdaloid CRF pathways. Role in autonomic, neuroendocrine, and behavioral responses to stress. Ann. N.Y. Acad. Sci. 697, 53-60.

Gray, T.S. and Magnuson, D.J. (1987). Neuropeptide neuronal efferents from the bed nucleus of the stria terminalis and central amygdaloid nucleus to the dorsal vagal complex in the rat. J. Comp. Neurol. 262, 365-374.

Gray, T.S. and Magnuson, D.J. (1992). Peptide immunoreactive neurons in the amygdala and the bed nucleus of the stria terminalis project to the midbrain central gray in the rat. Peptides 13, 451-460. 
Gray, T.S., Carney, M.E., and Magnuson, D.J. (1989). Direct projections from the central amygdaloid nucleus to the hypothalamic paraventricular nucleus: possible role in stress-induced adrenocorticotropin release. Neuroendocrinology $50,433-446$.

Greenwood-Van Meerveld, B., Gibson, M., Gunter, W., Shepard, J., Foreman, R., and Myers, D. (2001). Stereotaxic delivery of corticosterone to the amygdala modulates colonic sensitivity in rats. Brain Res. 893, 135-142.

Gregus, A., Wintink, A.J., Davis, A.C., and Kalynchuk, L.E. (2005). Effect of repeated corticosterone injections and restraint stress on anxiety and depression-like behavior in male rats. Behav. Brain Res. 156, 105-114.

Griebel, G., Perrault, G., and Sanger, D.J. (1998). Characterization of the behavioral profile of the non-peptide CRF receptor antagonist CP-154,526 in anxiety models in rodents: comparison with diazepam and buspirone. Psychopharmacology 138, 55-66.

Griebel, G., Simiand, J., Steinberg, R., Jung, M., Gully, D., Roger, P., Geslin, M., Scatton, B., Maffrand, J.P., and Soubrié, P. (2002). 4-(2-Chloro-4-methoxy-5methylphenyl)-N-[(1S)-2-cyclopropyl-1-(3-fluoro-4-methylphenyl)ethyl]5-methylN-(2-propynyl)-1, 3-thiazol-2-amine hydrochloride (SSR125543A), a potent and selective corticotrophin-releasing factor(1) receptor antagonist. II. Characterization in rodent models of stress-related disorders. J. Pharmacol. Exp. Ther. 301, 333-345.

Gutman, D.A., Owens, M.J., Thrivikraman, K.V., and Nemeroff, C.B. (2011). Persistent anxiolytic affects after chronic administration of the CRF-1 receptor antagonist R121919 in rats. Neuropharmacology 60, 1135-1141. 
Gutman, D.A., Coyer, M.J., Boss-Williams, K.A., Owens, M.J., Nemeroff, C.B., and Weiss, J.M. (2008). Behavioral effects of the CRF1 receptor antagonist R121919 in rats selectively bred for high and low activity in the swim test. Psychoneuroendocrinology 33, 1093-1101.

Haller, J., Aliczki, M., and Gyimesine Pelczer, K. (2013). Classical and novel approaches to the preclinical testing of anxiolytics: a critical evaluation. Neurosci. Biobehav. Rev. 37, 2318-2330.

Han, F., Ding, J., and Shi, Y. (2014). Expression of amygdala mineralocorticoid receptor and glucocorticoid receptor in the single-prolonged stress rats. BMC Neurosci. 15, 77.

Harding, A., Paxinos, G., and Halliday, G. (2004). The serotonin and tachykinin systems. In: G. Paxinos, ed. The rat nervous system, 3rd ed. (Amsterdam: Elsevier), pp. 1205-1256.

Härfstrand, A., Fuxe, K., Cintra, A., Agnati, L.F., Zini, I., Wikström, A.C., Okret, S., Yu, Z.Y., Goldstein M., Steinbusch H., Verhofstad, A., and Gustafsson, J.-A. (1986). Glucocorticoid receptor immunoreactivity in monoaminergic neurons of rat brain. Proc. Natl Acad. Sci. U.S.A. 83, 9779-9783.

Harro, J., Tõnissaar, M., and Eller, M. (2001). The effects of CRA 1000, a nonpeptide antagonist of corticotropin-releasing factor receptor type 1, on adaptive behaviour in the rat. Neuropeptides 35, 100-109.

Hascoët, M., Bourin, M., Nic Dhonnchadha, B.A. (2001). The mouse light-dark paradigm: a review. Prog. Neuropsychopharmacol. Biol. Psychiatry. 25, 141166.

Hashimoto, K., Maskino, S., Asaba, K., and Nishiyama. M. (2001). Physiological roles of corticotropin-releasing hormone receptor type 2. Endocr. J. 48, 1-9. 
Hauger, R.L., Risbrough, V., Brauns, O., and Dautzenberg, F.M. (2006). Corticotropin releasing factor (CRF) receptor signaling in the central nervous system: new molecular targets. CNS Neurol. Disord. Drug Targets 5, 453-479.

Hauger, R.L., Risbrough, V., Oakley, R.H., Olivares-Reyes, J.A., and Dautzenberg, F.M. (2009). Role of CRF receptor signaling in stress vulnerability, anxiety, and depression. Ann. NY Acad. Sci. 1179, 120-143.

He, L.Q., Gilligan, P.J., Zaczek, R., Fitzgerald, L.W., McElroy, J., Shen, H.S.L., Saye, J.A., Kalin, N.H., Shelton, S., Christ, D., Trainor, G., and Hartig, P. (2000). 4(1,3-dimethoxyprop-2-ylamino)-2,7-dimethyl-8-(2,4-dichlorophenyl)pyrazolo[1,5-a]1,3,5-triazine: a potent, orally bioavailable CRF1 receptor antagonist. J. Med. Chem. 43, 449-456.

Heinrichs, S.C. and Koob, G.F. (2004). Corticotropin-releasing factor in brain: a role in activation, arousal, and affect regulation. J. Pharmacol. Exp. Ther. 311, 427440.

Heinrichs, S.C., De Souza, E.B., Schulteis, G., Lapsansky, J.L., and Grigoriadis, D.E. (2002). Brain penetrance, receptor occupancy and antistress in vivo efficacy of a small molecule corticotropin releasing factor type I receptor selective antagonist. Neuropsychopharmacology 27, 194-202.

Heinrichs, S.C., Lapsansky, J., Lovenberg, T.W., De Souza, E.B., and Chalmers, D.T. (1997). Corticotropin-releasing factor CRF1, but not CRF2, receptors mediate anxiogenic-like behavior. Regul. Pept. 71, 15-21.

Heinrichs, S.C., Pich, E.M., Miczek, K., Britton, K.T., and Koob, G.F. (1992). Corticotropin-releasing factor antagonist reduces emotionality in socially defeated rats via direct neurotropic action. Brain Res. 581, 190-197. 
Heinrichs, S.C., Menzaghi, F., Merlo-Pich, E., Baldwin, H.A., Rassnick, S., Britton, K.T., and Koob, G.F. (1994). Anti-stress action of a corticotropin-releasing factor antagonist on behavioral reactivity to stressors of varying type and intensity, Neuropsychopharmacology 11, 179-186.

Henry, B., Vale, W., and Markou, A. (2006). The effect of lateral septum corticotropinreleasing factor receptor 2 activation on anxiety is modulated by stress. J. Neurosci. 26, 9142-9152.

Hensler, J.G. (2006). Serotonergic modulation of the limbic system. Neurosci. Biobehav. Rev. 30, 203-214.

Herman, J.P. (1993). Regulation of adrenocorticosteroid receptor mRNA expression in the central nervous system. Cell Mol. Neurobiol. 13, 349-372.

Hlavacova, N. and Jezova, D. (2008). Chronic treatment with the mineralocorticoid hormone aldosterone results in increased anxiety-like behavior. Horm. Behav. $54,90-97$.

Hlavacova, N., Bakos, J., and Jezova, D. (2010). Eplerenone, a selective mineralocorticoid receptor blocker, exerts anxiolytic effects accompanied by changes in stress hormone release. J. Psychopharmacol. 24, 779-786.

Hodgson, R.A., Higgins, G.A., Guthrie, D.H., Lu, S.X., Pond, A.J., Mullins, D.E., Guzzi, M.F., Parker, E.M., and Varty, G.B. (2007). Comparison of the V1b antagonist, SSR149415, and the CRF1 antagonist, CP-154,526, in rodent models of anxiety and depression. Pharmacol. Biochem. Behav. 86, 431-440.

Hogg, S. (1996). A review of the validity and variability of the elevated plus-maze as an animal model of anxiety. Pharmacol. Biochem. Behav. 54, 21-30.

Horvath, K.M., Meerlo, P., Felszeghy, K., Nyakas, C., and Luiten, P.G. (1999). Early postnatal treatment with ACTH4-9 analog ORG 2766 improves adult spatial 
learning but does not affect behavioural stress reactivity. Behav. Brain Res. 106, 181-188.

Howard, E. and Granoff, D.M. (1968). Increased voluntary running and decreased motor coordination in mice after neonatal corticosterone implantation. Exp. Neurol. 22, 661-673.

Isogawa, K., Akiyoshi, J., Tsutsumi, T., Kodama, K., Horinouti, Y., and Nagayama, H. (2003). Anxiogenic-like effect of corticotropin-releasing factor receptor 2 antisense oligonucleotides infused into rat brain. J. Psychopharmacol. 17, 409413.

Jaferi, A. and Bhatnagar, S. (2007). Corticotropin-releasing hormone receptors in the medial prefrontal cortex regulate hypothalamic-pituitary-adrenal activity and anxiety-related behavior regardless of prior stress experience. Brain Res. 1186, 212-223.

Jahn, H., Montkowski, A., Knaudt, K., Ströhle, A., Kiefer, F., Schick, M., and Wiedemann, K. (2001). Alpha-helical-corticotropin-releasing hormone reverses anxiogenic effects of C-type natriuretic peptide in rats. Brain Res. 893, 21-28.

Jaszberenyi, M., Bujdosó, E., Bagosi, Z., and Telegdy, G. (2006). Mediation of the behavioral, endocrine and thermoregulatory actions of ghrelin. Horm. Behav. $50,266-273$.

Jaszberenyi, M., Bagosi, Z., Thurzó, B., Földesi, I., and Telegdy, G. (2007). Endocrine and behavioral effects of neuromedin S. Horm. Behav. 52, 631-639. Jazayeri, A. and Meyer, W.J. 3rd. (1988). Glucocorticoid modulation of betaadrenergic receptors of cultured rat arterial smooth muscle cells. Hypertension 12, 393-398. 
Joëls, M. and de Kloet, E.R. (1989). Effects of glucocorticoids and norepinephrine on the excitability in the hippocampus. Science 245, 1502-1505.

Jones, D.N.C., Kortekaas, R., Slade, P.D., Middlemiss, D.N., and Hagan, J.J. (1998). The behavioural effects of corticotropin-releasing factor-related peptides in rats. Psychopharmacology 138, 124-132.

Kagamiishi, Y., Yamamoto, T., and Watanabe, S. (2003). Hippocampal serotonergic system is involved in anxiety-like behavior induced by corticotropin-releasing factor. Brain Res. 991, 212-221.

Kalin, N.H., Shelton, S.E., Kraemer, G.W., and McKinney, W.T. (1983). Corticotropinreleasing factor administered intraventricularly to rhesus monkeys. Peptides 4 , 217-220.

Kalivas, P.W., Duffy, P., and Latimer, L.G. (1987). Neurochemical and behavioral effects of corticotropin-releasing factor in the ventral tegmental area of the rat. J. Pharmacol. Exp. Ther. 242, 757-763.

Kalynchuk, L.E., Gregus, A., Boudreau, D., and Perrot-Sinal, T.S. (2004). Corticosterone increases depression-like behavior, with some effects on predator odor-induced defensive behavior, in male and female rats. Behav. Neurosci. 118, 1365-1377.

Karalis, K., Sano, H., Redwine, J., Listwak, S., Wilder, R.L., and Chrousos, G.P. (1991). Autocrine or paracrine inflammatory actions of corticotropinreleasing hormone in vivo. Science 254, 421-423.

Karolyi, I.J., Burrows, H.L., Ramesh, T.M., Nakajima, M., Lesh, J.S., Seong, E., Camper, S.A., and Seasholtz, A.F. (1999). Altered anxiety and weight gain in corticotropin-releasing hormone-binding protein-deficient mice. Proc. Natl Acad. Sci. U.S.A. 96, 11595-11600. 
Kasahara, M., Groenink, L., Breuer, M., Olivier, B., and Sarnyai, Z. (2007). Altered behavioural adaptation in mice with neural corticotrophin-releasing factor overexpression. Genes Brain Behav. 6, 598-607.

Keay, K.A. and Bandler, R. (2004). Periaqueductal grey. In: G. Paxinos, ed. The rat nervous system, 3rd ed. (Amsterdam: Elsevier), pp. 243-257.

Keck, M.E., Welt, T., Wigger, A., Renner, U., Engelmann, M., Holsboer, F., and Landgraf, R. (2001). The anxiolytic effect of the $\mathrm{CRH}(1)$ receptor antagonist R121919 depends on innate emotionality in rats. Eur. J. Neurosci. 13, 373-380.

Keenan, C.R., Lew, M.J., and Stewart, A.G. (2016). Biased signalling from the glucocorticoid receptor: renewed opportunity for tailoring glucocorticoid activity. Biochem. Pharmacol. 112, 6-12.

Keller-Wood, M.E. and Dallman, M.F. (1984). Corticosteroid inhibition of ACTH secretion. Endocr. Rev. 5, 1-24.

Kerr, D.S., Campbell, L.W., Hao, S.Y., and Landfield, P.W. (1989). Corticosteroid modulation of hippocampal potentials: increased effect with aging. Science 245, 1505-1509.

Kim, H., Yi, J.H., Choi, K., Hong, S., Shin, K.S., and Kang, S.J. (2014). Regional differences in acute corticosterone-induced dendritic remodeling in the rat brain and their behavioral consequences. BMC Neurosci. 15, 65 .

Kishimoto, T., Radulovic, J., Radulovic, M., Lin, C.R., Schrick, C., Hooshmand, F., Hermanson, O., Rosenfeld, M.G., and Spiess, J. (2000). Deletion of crhr2 reveals an anxiolytic role for corticotropin-releasing hormone receptor-2. Nat. Genet. 24, 415-419.

Kliethermes, C.L. (2005). Anxiety-like behaviors following chronic ethanol exposure. Neurosci. Biobehav. Rev. 28, 837-850. 
Kliethermes, C.L. and Crabbe, J.C. (2006). Pharmacological and genetic influences on hole-board behaviors in mice. Pharmacol. Biochem. Behav. 85, 57-65.

Koob, G.F. and Bloom, F.E. (1985). Corticotropin-releasing factor and behavior. Fed. Proc. 44, 259-263.

Koob, G.F. and Heinrichs, S.C. (1999). A role for corticotropin releasing factor and urocortin in behavioral responses to stressors. Brain Res. 848, 141-152.

Koob, G.F. and Thatcher-Britton, K. (1985). Stimulant and anxiogenic effects of corticotropin releasing factor. Prog. Clin. Biol. Res. 192, 499-506.

Koob, G.F., Heinrichs, S.C., Pich, E.M., Menzaghi, F., Baldwin, H., Miczek, K., and Britton, K.T. (1993). The role of corticotropin-releasing factor in behavioural responses to stress. Ciba Found. Symp. 172, 277-289.

Korte, S.M., de Boer, S.F., de Kloet, E.R., and Bohus, B. (1995). Anxiolytic-like effects of selective mineralocorticoid antagonists on fear-enhanced behavior in the elevated plus-maze. Psychoneuroendocrinology 20, 385-394.

Kulesskaya, N. and Voikar, V. (2014). Assessment of mouse anxiety-like behavior in the light-dark box and open-field arena: role of equipment and procedure. Physiol. Behav. 133, 30-38.

Kulkarni, S.K. and Sharma, A.C. (1991). Elevated plus-maze: a novel psychobehavioral tool to measure anxiety in rodents. Methods Find. Exp. Clin. Pharmacol. 13, 573-577.

Kumar, K.B. and Karanth, K.S. (1996). Alpha-helical CRF blocks differential influence of corticotropin releasing factor (CRF) on appetitive and aversive memory retrieval in rats. J. Neural Transm. 103, 1117-1126. 
Kur'yanova, E.V., Teplyi, D.L., Zhukova, Y.D., and Zhukovina, N.V. (2015). Heart rate variability in nonlinear rats with different orientation and exploratory activity in the open field. Bull. Exp. Biol. Med. 160, 183-186.

Lalonde, R. and Strazielle, C. (2012). Relations between open-field, elevated plusmaze, and emergence tests in C57BL/6Jlco and BALB/CAnN@Ico mice injected with ethanol. Fund. Clin. Pharmacol. 26, 271-278.

Lalonde, R. and Strazielle, C. (2010). Relations between open-field, elevated plusmaze, and emergence tests in C57BL/6J and BALB/c mice injected with GABAand 5HT-anxiolytic agents. Fund. Clin. Pharmacol. 24, 365-376.

Lalonde, R. and Strazielle, C. (2008). Relations between open-field, elevated plusmaze, and emergence tests as displayed by C57BL/6J and BALB/c mice. J. Neurosci. Methods 171, 48-52.

Laue, L., Loriaux, D.L., and Chrousos, G.P. (1988). Glucocorticoid antagonists and the role of glucocorticoids at the resting and stress state. Adv. Exp. Med. Biol. 245, 225-235.

Lecorps, B., Rödel, H.G., and Féron, C. (2016). Assessment of anxiety in open field and elevated plus maze using infrared thermography. Physiol. Behav. 157, 209216.

Lee, B., Sur, B., Kwon, S., Yeom, M., Shim, I., Lee, H., and Hahm, D.H. (2013). Chronic administration of catechin decreases depression and anxiety-like behaviors in a rat model using chronic corticosterone injections. Biomol. Ther. (Seoul) 21, 313-322.

Lee, E.H. and Tsai, M.J. (1989). The hippocampus and amygdala mediate the locomotor stimulating effects of corticotropin-releasing factor in mice. Behav. Neural Biol. 51, 412-423. 
Lee, E.H., Tang, Y.P., and Chai, C.Y. (1987). Stress and corticotropin-releasing factor potentiate center region activity of mice in an open field. Psychopharmacology 93, 320-323.

Lee, E.H.Y., Tsai, M.J., and Chai, C.Y. (1986). Stress selectively influences center region activity of mice in an open field. Physiol. Behav. 37, 659-662.

Lee, R.S., Tamashiro, K.L., Yang, X., Purcell, R.H., Harvey, A., Willour, V.L., Huo, Y., Rongione, M, Wand, GS, and Potash, J.B. (2010). Chronic corticosterone exposure increases expression and decreases deoxyribonucleic acid methylation of Fkbp5 in mice. Endocrinology 151, 4332-4343.

Lee, Y., Fitz, S., Johnson, P.L., and Shekhar, A. (2008). Repeated stimulation of CRF receptors in the BNST of rats selectively induces social but not panic-like anxiety. Neuropsychopharmacology 33, 2586-2594.

Lelas, S., Wong, H., Li, Y.W., Heman, K.L., Ward, K.A., Zeller, K.L., Sieracki, K.K., Polino, J.L., Godonis, H.E., Ren, S.X., Yan, X.X., Arneric, S.P., Robertson, D.W., Hartig, P.R., Grossman, S., Trainor, G.L., Taub, R.A., Zaczek, R., Gilligan, P.J., and McElroy, J.F. (2004). Anxiolytic-like effects of the corticotropin-releasing factor1 (CRF1) antagonist DMP904 [4-(3-pentylamino)2,7-dimethyl-8-(2-methyl-4-methoxyphenyl)-pyrazolo-[1,5-a]-pyrimidine] administered acutely or chronically at doses occupying central CRF1 receptors in rats. J. Pharmacol. Exp. Ther. 309, 293-302.

Lewejohann, L., Reinhard, C., Schrewe, A., Brandewiede, J., Haemisch, A., Görtz, N., Schachner, M., and Sachser, N. (2006). Environmental bias? Effects of housing conditions, laboratory environment and experimenter on behavioral tests. Genes Brain Behav. 5, 64-72. 
Li, C., Vaughan, J., Sawchenko, P.E., and Vale, W.W. (2002). Urocortin 3-immunoreactive projections in rat brain: partial overlap with sites of type 2 corticotrophin-releasing factor receptor expression, J. Neurosci. 22, 991-1001.

Li, X.F., Hu, M.H., Li, S.Y., Geach, C., Hikima, A., Rose, S., Greenwood, M.P., Greenwood, M., Murphy, D., Poston, L., Lightman, S.L., and O'Byrne, K.T. (2014). Overexpression of corticotropin releasing factor in the central nucleus of the amygdala advances puberty and disrupts reproductive cycles in female rats. Endocrinology 155, 3934-3944.

Liang, K.C. and Lee, E.H. (1988). Intra-amygdala injections of corticotropin releasing factor facilitate inhibitory avoidance learning and reduce exploratory behavior in rats. Psychopharmacology 96, 232-236.

Liebsch, G., Landgraf, R., Engelmann, M., Lörscher P., and Holsboer F. (1999). Differential behavioural effects of chronic infusion of $\mathrm{CRH} 1$ and $\mathrm{CRH} 2$ receptor antisense oligonucleotides into the rat brain. J. Psychiat. Res. 33, 153-163.

Liebsch, G., Landgraf, R., Gerstberger, R., Probst, J.C., Wotjak, C.T., Engelmann, M., Holsboer, F., and Montkowski, A. (1995). Chronic infusion of a CRH1 receptor antisense oligodeoxynucleotide into the central nucleus of the amygdala reduced anxiety-related behavior in socially defeated rats. Regul. Pept. 59, 229-239.

Lim, H., Jang, S., Lee, Y., Moon, S., Kim, J., and Oh, S. (2012). Enhancement of anxiety and modulation of TH and pERK expressions in amygdala by repeated injections of corticosterone. Biomol. Ther. 20, 418-424.

Liu, W. and Zhou, C. (2012). Corticosterone reduces brain mitochondrial function and expression of mitofusin, BDNF in depression-like rodents regardless of exercise preconditioning. Psychoneuroendocrinology 37, 1057-1070. 
Lorivel, T., Gras, M., and Hilber, P. (2010). Effects of corticosterone synthesis inhibitor metyrapone on anxiety-related behaviors in Lurcher mutant mice. Physiol. Behav. 101, 309-314.

Lundkvist. J., Chai. Z., Teheranian. R., Hasanva, H., Bartfai, T., Jenck, F., Widmer, U., and Moreau, J.L (1996). A non-peptidic corticotropin releasing factor receptor antagonist attenuates fever and exhibits anxiolytic-like activity. Eur. J. Pharmacol. 309, 195-200.

Madruga, C., Xavier, L.L., Achaval, M., Sanvitto, G.L., and Lucion, A.B. (2006). Early handling, but not maternal separation, decreases emotional responses in two paradigms of fear without changes in mesolimbic dopamine. Behav. Brain Res. $166,241-246$.

Mansi, J.A., Rivest, S., and Drolet, G. (1996). Regulation of corticotropin-releasing factor type 1 (CRF1) receptor messenger ribonucleic acid in the paraventricular nucleus of rat hypothalamus by exogenous CRF. Endocrinology 137, 46194629.

Marin, M.T., Cruz, F.C., and Planeta, C.S. (2007). Chronic restraint or variable stresses differently affect the behavior, corticosterone secretion and body weight in rats. Physiol. Behav. 90, 29-35.

Marinelli, M., Rougé-Pont, F., De Jesus-Oliveira, C., Le Moal, M., and Piazza, P.V. (1997). Acute blockade of corticosterone secretion decreases the psychomotor stimulant effects of cocaine. Neuropsychopharmacology 16, 156-161.

Marks, W., Fournier, N.M., and Kalynchuk, L.E. (2009). Repeated exposure to corticosterone increases depression-like behavior in two different versions of the forced swim test without altering nonspecific locomotor activity or muscle strength. Physiol. Behav. 98, 67-72. 
Martins, A.P., Marras, R.A., and Guimarães, F.S. (2000). Anxiolytic effect of a CRH receptor antagonist in the dorsal periaqueductal gray. Depress. Anxiety 12, 99101.

Martins, A.P., Marras, R.A., and Guimarães, F.S. (1997). Anxiogenic effect of corticotropin-releasing hormone in the dorsal periaqueductal grey. NeuroReport 8, 3601-3604

Matsumoto, Y., Abe, M., Watanabe, T., Adachi, Y., Yano, T., Takahashi, H., Sugo, T., Mori, M., Kitada, C., Kurokawa, T., and Fujino, M. (2004). Intracerebroventricular administration of urotensin II promotes anxiogenic-like behaviors in rodents. Neurosci. Lett. 358, 99-102.

McEwen, B.S., Davis, P.G., Parsons, B., and Pfaff, D.W. (1979). The brain as a target for steroid hormone action. Annu. Rev. Neurosci. 2, 65-112.

McEown, K. and Treit, D. (2011). Mineralocorticoid receptors in the medial prefrontal cortex and hippocampus mediate rats' unconditioned fear behaviour. Horm. Behav. 60, 581-588.

McKlveen, J.M., Myers, B., Flak, J.N., Bundzikova, J., Solomon, M.B., Seroogy, K.B., and Herman, J.P. (2013). Role of prefrontal cortex glucocorticoid receptors in stress and emotion. Biol. Psychiatry 74, 672-679.

Meaney, M.J., Aitken, D.H., van Berkel, C., Bhatnagar, S., and Sapolsky, R.M. (1988). Effect of neonatal handling on age-related impairments associated with the hippocampus. Science 239, 766-768.

Meaney, M.J., Aitken, D.H., Viau, V., Sharma, S., and Sarrieau, A. (1989). Neonatal handling alters adrenocortical negative feedback sensitivity and hippocampal type II glucocorticoid receptor binding in the rat. Neuroendocrinology 50, 597604. 
Meaney, M.J., O'Donnell, D., Rowe, W., Tannenbaum, B., Steverman, A., Walker, M., Nair, N.P., and Lupien, S. (1995). Individual differences in hypothalamicpituitary-adrenal activity in later life and hippocampal aging. Exp. Gerontol. 30, 229-251.

Menzaghi, F., Howard, R.L., Heinrichs, S.C., Vale, W., Rivier, J., and Koob, G.F. (1994). Characterization of a novel and potent corticotropin-releasing factor antagonist in rats, J. Pharmacol. Exp. Ther. 269, 564-572.

Merchenthaler, I., Vigh, S., Petrusz, P., and Schally, A.V. (1982). Immunocytochemical localization of corticotropin-releasing factor (CRF) in the rat brain. Am. J. Anat. 165, 385-396.

Miguel, T.T. and Nunes-de-Souza, R.L. (2011). Anxiogenic and antinociceptive effects induced by corticotropin-releasing factor (CRF) injections into the periaqueductal gray are modulated by CRF1 receptor in mice. Horm. Behav. 60 , 292-300.

Miguel, T.M., Gomes, K.S., and Nunes-de-Souza, R.L. (2014). Tonic modulation of anxiety-like behavior by corticotropin-releasing factor (CRF) type 1 receptor (CRF1) within the medial prefrontal cortex (MPFC) in male mice: role of protein kinase A (PKA). Horm. Behav. 66, 247-256.

Millan, M.J., Brocco, M., Gobert, A., Dorey, G., Casara, P., and Dekeyne, A. (2001). Anxiolytic properties of the selective, non-peptidergic corticotropin-releasing factor (CRF)1 antagonists, CP154,526 and DMP 695: a comparison to other classes of anxiolytic agent, Neuropsychopharmacology 25, 585-600.

Miller, A.L., Chaptal, C., McEwen, B.S., and Peck, E.J. Jr (1978). Modulation of high affinity GABA uptake into hippocampal synaptosomes by glucocorticoids. Psychoneuroendocrinology 3, 155-164. 
Misslin, R., Belzung, C., and Vogel, E. (1989). Behavioural validation of a light/dark choice procedure for testing anti-anxiety agents. Behav. Processes 18, 119132.

Mitra, R. and Sapolsky, R.M. (2008). Acute corticosterone treatment is sufficient to induce anxiety and amygdaloid dendritic hypertrophy. Proc. Natl Acad. Sci. U.S.A. $105,5573-5578$.

Mitra, R. and Sapolsky, R.M. (2010). Expression of chimeric estrogen-glucocorticoidreceptor in the amygdala reduces anxiety. Brain Res. 1342, 33-38.

Mitra, R., Ferguson, D., and Sapolsky, R.M. (2009). Mineralocorticoid receptor overexpression in basolateral amygdala reduces corticosterone secretion and anxiety. Biol. Psychiatry 66, 686-690.

Moreau, J.L., Kilpatrick, G., and Jenck, F. (1997). Urocortin, a novel neuropeptide with anxiogenic-like properties. NeuroReport 8, 1697-701.

Moore, R.Y. and Bloom, F.E. (1979). Central catecholamine neuron systems: anatomy and physiology of the norepinephrine and epinephrine systems. Annu. Rev. Neurosci. 2, 113-168.

Mori, K., Miyazato, M., and Kangawa, K. (2008). Neuromedin S: discovery and functions. Results Probl. Cell Differ. 46, 201-212.

Morimoto, M., Morita, N., Ozawa, H., Yokoyama, K., and Kawata, M. (1996). Distribution of glucocorticoid receptor immunoreactivity and mRNA in the rat brain: an immunohistochemical and in situ hybridization study. Neurosci. Res. 26, 235-269.

Müller, M.B., Zimmermann, S., Sillaber, I., Hagemeyer, T.P., Deussing, J.M., Timpl, P., Kormann, M.S., Droste, S.K., Kühn, R., Reul, J.M., Holsboer, F., and Wurst, W. (2003). Limbic corticotropin-releasing hormone receptor 1 mediates anxiety- 
related behavior and hormonal adaptation to stress. Nat. Neurosci. 6, 11001107.

Murphy, B.E. (1967). Some studies of the protein binding of steroids and their application to the routine micro and ultramicro measurement of various steroids in body fluids by competitive protein binding radioassay. J. Clin. Endocr. 27, 973-990.

Murray, F., Smith, D.W., and Hutson, P.H. (2008). Chronic low dose corti- costerone exposure decreased hippocampal cell proliferation, volume and induced anxiety and depression like behaviours in mice. Eur. J. Pharmacol. 583, 115-127.

Myers, B. and Greenwood-Van Meerveld, B. (2007). Corticosteroid receptormediated mechanisms in the amygdala regulate anxiety and colonic sensitivity. Am. J. Physiol. Gastrointest. Liver Physiol. 292, G1622-G1629.

Myers, B. and Greenwood-Van Meerveld, B. (2010). Divergent effects of amygdala glucocorticoid and mineralocorticoid receptors in the regulation of visceral and somatic pain. Am. J. Physiol. Gastrointest. Liver Physiol. 298, G295-G303.

Nolan, N.A. and Parkes, M.W. (1973). The effects of benzodiazepines on the behaviour of mice on a hole-board. Psychopharmacologia 29, 277-286.

Ohata, H. and Shibasaki, T. (2011). Microinjection of different doses of corticotropinreleasing factor into the medial prefrontal cortex produces effects opposing anxiety-related behavior in rats. J. Nippon Med. Sch. 78, 286-292.

Ohmura, Y., Yamaguchi, T., Izumi, T., Matsumoto, M., and Yoshioka, M. (2008). Corticotropin releasing factor in the median raphe nucleus is involved in the retrieval of fear memory in rats. Eur. J. Pharmacol. 584, 357-360. 
Oitzl, M.S., Fluttert, M., and de Kloet, E.R. (1994). The effect of corticosterone on reactivity to spatial novelty is mediated by central mineralocorticosteroid receptors. Eur. J. Neurosci. 6, 1072-1079.

Oitzl, M.S., Fluttert, M., Sutanto, W., and de Kloet, E.R. (1998). Continuous blockade of brain glucocorticoid receptors facilitates spatial learning and memory in rats. Eur. J. Neurosci. 10, 3759-3766.

Okuyama, S., Chaki, S., Kawashima, N., Suzuki, Y., Ogawa, S., Nakazato, A., Kumagai, T., Okubo, T., and Tomisawa, K. (1999). Receptor binding, behavioral, and electrophysiological profiles of nonpeptide corticotropinreleasing factor subtype 1 receptor antagonists CRA1000 and CRA1001. J. Pharmacol. Exp. Ther. 289, 926-935.

O'Malley, D., Julio-Piepera, M., Dinan, T.G., and Cryan, J.F. (2014). Strain differences in stress-induced changes in central CRF1 receptor expression. Neurosci. Lett. 561, 192-197.

Onaivi, E.S. and Martin, B.R. (1989). Neuropharmacological and physiological validation of a computer-controlled two-compartment black and white box for the assessment of anxiety. Prog. Neuropsychopharmacol. Biol. Psychiatry 13, 963-976.

Orozco-Cabal, L., Pollandt, S., Liu, J., Shinnick-Gallagher, P., and Gallagher, J.P. (2006). Regulation of synaptic transmission by CRF receptors. Rev. Neurosci. $17,279-307$

Padoin, M.J., Cadore, L.P., Gomes, C.M., Barros, H.M.T., and Lucion, A. B. (2001). Long-lasting effects of neonatal handling stimulation in the behavior of rats. Behav. Neurosci. 115, 1332-1340. 
Paré, W.P., Tejani-Butt, S., and Kluczynski, J. (2001). The emergence test: effects of psychotropic drugs on neophobic disposition in Wistar Kyoto (WKY) and Sprague Dawley rats. Prog Neuropsychopharmacol. Biol. Psychiatry 25, 16151628.

Pego, J.M., Morgado, P., Pinto, L.G., Cerqueira, J.J., Almeida, O.F., and Sousa, N. (2008). Dissociation of the morphological correlates of stress-induced anxiety and fear. Eur. J. Neurosci. 27, 1503-1516.

Pelleymounter, M.A., Joppa, M., Ling, N., and Foster, A.C. (2002). Pharmacological evidence supporting a role for central corticotropin-releasing factor(2) receptors in behavioral, but not endocrine, response to environmental stress. J. Pharmacol. Exp. Ther. 302, 145-152.

Pelleymounter, M.A., Joppa, M., Ling, N., and Foster, A.C. (2004). Behavioral and neuroendocrine effects of the selective CRF2 receptor agonists urocortin II and urocortin III. Peptides 25, 659-666.

Pellow, S. and File, S.E. (1985). The effects of putative anxiogenic compounds (FG 7142, CGS 8216 and Ro 15-1788) on the rat corticosterone response. Physiol. Behav. 35, 587-590.

Pellow, S., Chopin, P., File, S.E., and Briley, M. (1985). Validation of open:closed arm entries in an elevated plus-maze as a measure of anxiety in the rat. J. Neurosci. Methods 14, 149-167.

Pentkowski, N.S., Litvin, Y., Blanchard, D.C., Vasconcellos, A., King, L.B., and Blanchard, R.J. (2009). Effects of acidic-astressin and ovine-CRF microinfusions into the ventral hippocampus on defensive behaviors in rats. Horm. Behav. 56, 35-43. 
Phelix, C.F. and Paull, W.K. (1990). Demonstration of distinct corticotropin releasing factor-containing neuron populations in the bed nucleus of the stria terminalis. A light and electron microscopic immunocytochemical study in the rat. Histochemistry 94, 345-364.

Pinheiro, S.H., Zangrossi, H. Jr., Del-Ben, C.M., and Graeff, F.G. (2007). Elevated mazes as animal models of anxiety: effects of serotonergic agents. An. Acad. Bras. Cienc. 79, 71-85.

Potter, E., Sutton, S., Donaldson, C., Chen, R., Perrin, M., Lewis, K., Sawchenko, P.E., and Vale W. (1994). Distribution of corticotropin- releasing factor receptor mRNA expression in the rat brain and pituitary. Proc. Natl Acad. Sci. U.S.A. 91, 8777-8781.

Prut, L. and Belzung, C. (2003). The open field as a paradigm to measure the effects of drugs on anxiety-like behaviors: a review. Eur. J. Pharmacol. 463, 3-33.

Rabasa, C., Gagliano, H., Pastor-Ciurana, J., Fuentes, S., Belda, X., Nadal, R., and Armario, A. (2015). Adaptation of the hypothalamus-pituitary-adrenal axis to daily repeated stress does not follow the rules of habituation: a new perspective. Neurosci. Biobehav. Rev. 56, 35-49.

Radulovic, J., Ruhman, A., Leipold, R., and Spiess, J. (1999). Modulation of learning and anxiety by corticotropin releasing factor (CRF) and stress: differential roles of CRF receptors 1 and 2. J. Neurosci. 19, 5016-5025.

Raineki, C., Lucion, A.B., and Weinberg, J. (2014). Neonatal handling: an overview of the positive and negative effects. Dev. Psychobiol. 56, 1613-1625.

Rainer, Q., Xia, L., Guilloux, J.P., Gabriel, C., Mocaer, E., Hen, R., Enhamre, E., Gardier, A.M., and David, D.J. (2012). Beneficial behavioural and neurogenic 
effects of agomelatine in a model of depression/anxiety. Int. J. Neuropsychopharmacol. 15, 321-335.

Ramos, A. (2008). Animal models of anxiety: do I need multiple tests? Trends Pharmacol. Sci. 29, 493-498.

Ramos, A., Berton, O., Mormède, P., and Chaouloff, F. (1997). A multiple-test study of anxiety-related behaviours in six inbred rat strains. Behav. Brain Res. $85,57-$ 69.

Rassnick, S., Heinrichs, S.C., Britton, K.T., and Koob, G.F. (1993). Microinjection of a corticotropin-releasing factor antagonist into the central nucleus of the amygdala reverses anxiogenic-like effects of ethanol withdrawal. Brain Res. $605,25-32$

Regev, L., Tsoory, M., Gil, S., and Chen, A. (2012). Site-specific genetic manipulation of amygdala corticotropin-releasing factor reveals its imperative role in mediating behavioral response to challenge. Biol. Psychiatry 71, 317-326.

Regev, L., Neufeld-Cohen, A., Tsoory, M., Kuperman, Y., Getselter, D., Gil, S., and Chen, A. (2011). Prolonged and site-specific over-expression of corticotropinreleasing factor reveals differential roles for extended amygdala nuclei in emotional regulation. Mol. Psychiatry 16, 714-728.

Reul, J.M. and Holsboer, F. (2002). Corticotropin-releasing factor receptors 1 and 2 in anxiety and depression. Curr. Opin. Pharmacol. 2, 23-33.

Reul, J.M., Probst, J.C., Skutella, T., Hirschmann, M., Stec, I.S., Montkowski, A., Landgraf, R., and Holsboer, F. (1997). Increased stress-induced adrenocorticotropin response after long-term intracerebroventricular treatment of rats with antisense mineralocorticoid receptor oligodeoxynucleotides. Neuroendocrinology 65, 189-199. 
Risold, P.Y. and Swanson, L.W. (1997). Connections of the rat lateral septal complex. Brain Res. Rev. 24, 115-195.

Rey, M., Carlier, E., and Soumireu-Mourat, B. (1989). Effects of RU 486 on hippocampal slice electrophysiology in normal and adrenalectomized BALB/C mice. Neuroendocrinology 49, 120-124.

Rey, M., Carlier, E., Talmi, M., and Soumireu-Mourat, B. (1994). Corticosterone effects on long-term potentiation in mouse hippocampal slices. Neuroendocrinology 60, 36-41.

Reyes, T., Lewis, K., Perrin, M., Kunitake, K., Vaughan, J., Arias, C., Hogenesch, J., Gulyas, J., Rivier, J., Vale, W., and Sawchenko, PE. (2001). Urocortin II: a member of the corticotropin releasing factor (CRF) neuropeptide family that is selectively bound by type 2 CRF receptors. Proc. Natl Acad. Sci. U.S.A. 98, 2843-2848.

Rochford, J., Beaulieu, S., Rousse, I., Glowa, J.R., and Barden, N. (1997). Behavioral reactivity to aversive stimuli in a transgenic mouse model of impaired glucocorticoid (type II) receptor function: effects of diazepam and FG7142. Psychopharmacology 132, 145-152.

Rodgers, R.J. and Dalvi, A. (1997). Anxiety, defence and the elevated plus-maze. Neurosci. Biobehav. Rev. 21, 801-810.

Rodi, D., Zucchini, S., Simonato, M., Cifani, C., Massi, M., and Polidori, C. (2008). Functional antagonism between nociceptin/orphanin FQ (N/OFQ) and corticotropin-releasing factor (CRF) in the rat brain: evidence for involvement of the bed nucleus of the stria terminalis. Psychopharmacology 196, 523-531.

Rodriguez de Fonseca, F., Rubio, P., Menzaghi, F., Merlo-Pich, E., Rivier, J., Koob, G.F., and Navarro, M. (1996). Corticotropin-releasing factor (CRF) antagonist 
[D-Phe 12, NLE21,38, CalphaMeLeu37] CRF attenuates the acute actions of the highly potent cannabinoid receptor agonist HU-210 on defensive-withdrawal behavior in rats. J. Pharmacol. Exp. Ther. 276, 56-64.

Roozendaal, B., Bohus, B., and McGaugh, J.L. (1996). Dose-dependent suppression of adrenocortical activity with metyrapone: effects on emotion and memory. Psychoneuroendocrinology 21, 681-693.

Roth, K.A. and Katz, R.J. (1979). Stress, behavioral arousal, and open field activity- a reexamination of emotionality in the rat. Neurosci. Biobehav. Rev. 3, 247-263.

Saha, S. (2005). Role of the central nucleus of the amygdala in the control of blood pressure: descending pathways to medullary cardiovascular nuclei. Clin. Exp. Pharmacol. Physiol. 32, 450-456.

Sahuque, L.L., Kullberg, E.F., Mcgeehan, A.J., Kinder, J.R., Hicks, M.P., Blanton, M.G., Janak, P.H., and Olive, M.F. (2006). Anxiogenic and aversive effects of corticotropin-releasing factor (CRF) in the bed nucleus of the stria terminalis in the rat: role of CRF receptor subtypes. Psychopharmacology 186, 122-132.

Sandi, C., Venero, C., and Guaza, C. (1996a). Novelty-related rapid locomotor effects of corticosterone in rats. Eur. J. Neurosci. 8, 794-800.

Sandi, C., Venero, C., and Guaza, C. (1996b). Nitric oxide synthesis inhibitors prevent rapid behavioral effects of corticosterone in rats. Neuroendocrinology $63,446-453$.

Sandoval-Herrera. V., Trujillo-Ferrara, J.G., Miranda-Páez, A., De La Cruz, F., and Zamudio, S.R. (2011). Corticosterone microinjected into nucleus pontis oralis increases tonic immobility in rats. Horm. Behav. 60, 448-456.

Saper, C.B. (2004). Central autonomic system. In: G. Paxinos, ed. The rat nervous system, 3rd ed. (Amsterdam: Elsevier), pp. 761-796. 
Sapolsky, R.M., Romero, L.M., and Munck, A.U. (2000). How do glucocorticoids influence stress responses? Integrating permissive, suppressive, stimulatory, and preparative actions. Endocr. Rev. 21, 55-89.

Schulz, D.W., Mansbach, R.S., Sprouse, J., Braselton, J.P., Collins, J., Corman, M., Dunaiskis, A., Faraci, S., Schmidt, A.W., Seeger, T., Seymour, P., Tingley, F.D., III, Winston, E.N., Chen, Y.L., and Heym, J. (1996). CP-154,526: a potent and selective nonpeptide antagonist of corticotropin releasing factor receptors. Proc. Natl Acad. Sci. U.S.A. 93, 10477-10482.

Selye, H. (1976). Forty years of stress research: principal remaining problems and misconceptions. Can. Med. Assoc. J. 115, 53-56.

Seo, J.J., Lee, S.H., Lee, Y.S., Kwon, B.M., Ma, Y., Hwang, B.Y., Hong, J.T., and Oh, K.W. (2007). Anxiolytic-like effects of obovatol isolated from Magnolia obovata: involvement of GABA/benzodiazepine receptors complex. Prog. Neuropsychopharmacol. Biol. Psychiatry 31, 1363-1369.

Sergio, T.O., Spiacci, A. Jr, and Zangrossi, H. Jr (2014). Effects of dorsal periaqueductal gray CRF1- and CRF2-receptor stimulation in animal models of panic, Psychoneuroendocrinology 49, 321-330.

Seymour, P.A., Schmidt, A.W., and Schulz, D.W. (2003). The pharmacology of CP154,526, a non-peptide antagonist of the $\mathrm{CRH1}$ receptor: a review. CNS Drug Rev. 9, 57-96.

Shepard, J.D. and Myers, D.A. (2008). Strain differences in anxiety-like behavior: association with corticotropin-releasing factor. Behav. Brain Res. 186, 239-245.

Shepard, J.D., Barron, K.W., and Myers, D.A. (2000). Corticosterone delivery to the amygdala increases corticotropin-releasing factor mRNA in the central amygdaloid nucleus and anxiety-like behavior. Brain Res. 861, 288-295. 
Shepard, J.D., Barron, K.W., and Myers, D.A. (2003). Stereotaxic localization of corticosterone to the amygdala enhances hypothalamo-pituitary-adrenal responses to behavioral stress. Brain Res. 963, 203-213.

Sherrin, T., Todorovic, C., Zeyda, T., Tan, C.H., Wong, P.T., Zhu, Y.Z., and Spiess, J. (2009). Chronic stimulation of corticotropin-releasing factor receptor 1 enhances the anxiogenic response of the cholecystokinin system. Mol. Psychiatry 14, 291-307.

Shinonaga, Y., Takada, M., and Mizuno, N. (1992). Direct projections from the central amygdaloid nucleus to the globus pallidus and substantia nigra in the cat. Neuroscience 251, 691-703.

Silva, M.S., Pereira, B.A., Céspedes, I.C., Nascimento, J.O., Bittencourt, J.C., and Viana, M.B. (2014). Dorsomedial hypothalamus CRF type 1 receptors selectively modulate inhibitory avoidance responses in the elevated T-maze. Behav. Brain Res. 271, 249-257.

Sink, K.S., Chung, A., Ressler, K.J., Davis, M., and Walker, D.L. (2013a). Anxiogenic effects of CGRP within the BNST may be mediated by CRF acting at BNST CRFR1 receptors. Behav. Brain Res. 243, 286-293.

Sink, K.S., Walker, D.L., Freeman, S.M., Flandreau, E., Ressler, K.J., and Davis, M. (2013b). Effects of continuously enhanced corticotropin releasing factor expression within the bed nucleus of the stria terminalis on conditioned and unconditioned anxiety. Mol. Psychiatry 18, 308-319.

Skorzewska, A., Bidzinski, A., Lehner, M., Turzynska, D., Sobolewska, A., Wislowska-Stanek, A., Maciejak, P., Szyndler, J., and Plaznik, A. (2011). The localization of brain sites of anxiogenic-like effects of urocortin-2. Neuropeptides 45, 83-92. 
Skorzewska, A., Bidziński A., Lehner, M., Turzyńska, D., Wisłowska-Stanek A., Sobolewska A., Szyndler J., Maciejak P., Taracha E., and Płaznik A. (2006). The effects of acute and chronic administration of corticosterone on rat behavior in two models of fear responses, plasma corticosterone concentration, and cFos expression in the brain structures. Pharmacol. Biochem. Behav. 85, 522534.

Skutella, T., Probst, J.C., Renner, U., Holsboer, F., and Behl, C. (1998). Corticotropin-releasing hormone receptor (type I) antisense targeting reduces anxiety. Neuroscience $85,795-805$.

Skutella, T., Montkowski, A., Stöhr, T., Probst, J.C., Landgraf, R., Holsboer, F., and Jirikowski, G.F. (1994). Corticotropin-releasing hormone (CRH) antisense oligodeoxynucleotide treatment attenuates social defeat-induced anxiety in rats. Cell Mol. Neurobiol. 14, 579-588.

Smagin, G.N., Harris, R.B., and Ryan, D.H. (1996). Corticotropin-releasing factor receptor antagonist infused into the locus coeruleus attenuates immobilization stress-induced defensive withdrawal in rats. Neurosci. Lett. 220, 167-170.

Smith, G.W., Aubry, J.M., Dellu, F., Contarino, A., Bilezikjian, L.M., Gold, L.H., Chen, R., Marchuk, Y., Hauser, C., Bentley, C.A., Sawchenko, P.E., Koob, G.F., Vale, W., and Lee, K.F. (1998). Corticotropin releasing factor receptor 1-deficient mice display decreased anxiety, impaired stress response, and aberrant neuroendocrine development. Neuron 20, 1093-1102.

Smythe, J.W., Murphy, D., Timothy, C., and Costall B. (1997). Hippocampal mineralocorticoid, but not glucocorticoid, receptors modulate anxiety-like behavior in rats. Pharmacol. Biochem. Behav. 56, 507-513. 
Song, C., Earley, B., and Leonard, B.E. (1995). Behavioral, neurochemical, and immunological responses to CRF administration: is CRF a mediator of stress? Ann. N.Y. Acad. Sci. 771, 55-72.

Spadaro, F., Berridge, C.W., Baldwin, H.A., and Dunn, A.J. (1990). Corticotropinreleasing factor acts via a third ventricle site to reduce exploratory behavior in rats. Pharmacol. Biochem. Behav. 36, 305-309.

Spencer, R.L., Miller, A.H., Stein, M., and McEwen, B.S. (1991). Corticosterone regulation of type I and type II adrenal steroid receptors in brain, pituitary and immune tissue. Brain Res. 549, 236-246.

Spina, M., Merlo-Pich, E., Chan, R.K.W., Basso, A.M., Rivier, J., Vale, W., and Koob, G.F. (1996). Appetite suppressant effects of urocortin, a CRF-related neuropeptide. Science 273, 1561-1564.

Spina, M.G., Basso, A.M., Zorrilla, E.P., Heyser, C.J., Rivier, J., Vale, W., Merlo-Pich, E., Koob, G.F. (2000). Behavioral effects of central administration of the novel CRF antagonist astressin in rats. Neuropsychopharmacology 22, 230-239.

Spina, M.G., Merlo-Pich, E., Akwa, Y., Balducci, C., Basso, A.M., Zorrilla, E.P., Britton, K.T., Rivier, J., Vale, W.W., and Koob, G.F. (2002). Time-dependent induction of anxiogenic-like effects after central infusion of urocortin or corticotropin-releasing factor in the rat. Psychopharmacology 160, 113-121.

Steketee, J.D. and Goeders, N.E. (2002). Pretreatment with corticosterone attenuates the nucleus accumbens dopamine response but not the stimulant response to cocaine in rats. Behav. Pharmacol. 13, 593-601.

Steckler, T. and Holsboer, F. (1999). Corticotopin-releasing hormone receptor subtypes and emotion. Biol. Psychiatry 46, 1480-1508. 
Stenzel-Poore, M.P., Heinrichs, S.C., Rivest, S., Koob, G.F., and Vale, W.W. (1994). Overproduction of corticotropin-releasing factor in transgenic mice: a genetic model of anxiogenic behavior. J. Neurosci. 14, 2579-2584.

Sternberg, E.M., Hill, J.M., Chrousos, G.P., Kamilaris, T., Listwak, S.J., Gold, P.W., and Wilder, R.L. (1989). Inflammatory mediator-induced hypothalamic-pituitaryadrenal axis activation is defective in streptococcal cell wall arthritis-susceptible Lewis rats. Proc. Natl Acad. Sci. U.S.A. 86, 2374-2378.

Sternberg, E.M., Glowa, J.R., Smith, M.A., Calogero, A.E., Listwak, S.J., Aksentijevich, S., Chrousos G.P., Wilder R.L., and Gold P.W. (1992). Corticotropin releasing hormone related behavioral and neuroendocrine responses to stress in Lewis and Fischer rats. Brain Res. 570, 54-60.

Sterner, E.Y. and Kalynchuk, L.E. (2010). Behavioral and neurobiological consequences of prolonged glucocorticoid exposure in rats: relevance to depression. Prog. Neuropsychopharmacol. Biol. Psychiatry 34, 777-790.

Stock, H., Foradori, C., Ford, K., and Wilson, M.A. (2000). A lack of tolerance to the anxiolytic effects of diazepam on the plus-maze: comparison of male and female rats. Psychopharmacology 147, 362-370.

Stone, E.A., Lina, Y., Sarfraza, Y., and Quartermain, D. (2011). The role of the central noradrenergic system in behavioral inhibition. Brain Res. Rev. 67, 193208.

Stotz-Potter, E.H., Willis, L.R., and DiMicco, J.A. (1996). Muscimol acts in dorsomedial but not paraventricular hypothalamic nucleus to suppress cardiovascular effects of stress. J. Neurosci. 16, 1173-1179. 
Sturm, M., Becker, A., Schroeder, A., Bilkei-Gorzo, A., and Zimmer, A. (2015). Impact of chronic corticosterone application on depression-like behavior in C57BL/6N and C57BL/6J mice. Genes Brain Behav. 14, 292-300.

Suchecki, D., Duarte Palma, B., and Tufik, S. (2000). Pituitary-adrenal axis and behavioural responses of maternally deprived juvenile rats to the open field. Behav. Brain Res. 111, 99-106.

Sudakov, S.K., Nazarova, G.A., Alekseeva, E.V., and Bashkatova, V.G. (2013). Estimation of the level of anxiety in rats: differences in results of open-field test, elevated plus-maze test, and Vogel's conflict test. Bull. Exp. Biol. Med. 155, 295-297.

Sutton, R.E., Koob, G.F., Le Moal, M., Rivier, J., and Vale, W. (1982). Corticotropin releasing factor produces behavioural activation in rats. Nature 297, 331-333.

Swanson, L.W., Sawchenko, P.E., Rivier, J., and Vale, W.W. (1983). Organization of ovine corticotropin-releasing factor immunoreactive cells and fibers in the rat brain: an immunohistochemical study. Neuroendocrinology 36, 165-186.

Szakacs, J., Csabafi, K., Lipták, N., and Szabó, G. (2015). The effect of obestatin on anxiety-like behaviour in mice. Behav. Brain Res. 293, 41-45.

Sztainberg, Y., Kuperman, Y., Justice, N., and Chen, A. (2011). An anxiolytic role for CRF receptor type 1 in the globus pallidus. J. Neurosci. 31, 17416-17424.

Takahashi, L.K., Kalin, N.H., Vanden Burgt, J.A., and Sherman, J.E. (1989). Corticotropin-releasing factor modulates defensive-withdrawal and exploratory behavior in rats. Behav. Neurosci. 103, 648-654.

Takahashi, L.K., Ho, S.P., Livanov, V., Graciani, N., and Arneric, S.P. (2001). Antagonism of $\mathrm{CRF}(2)$ receptors produces anxiolytic behavior in animal models of anxiety. Brain Res. 902, 135-142. 
Takeda, H., Tsuji, M., and Matsumiya, T. (1998). Changes in head-dipping behavior in the hole-board test reflect the anxiogenic and/or anxiolytic state in mice. Eur. J. Pharmacol. 350, 21-29.

Tan, L.A., Xu, K., Vaccarino, F.J., Lovejoy, D.A., and Rotzinger, S. (2008). Repeated intracerebral teneurin C-terminal associated peptide (TCAP)-1 injections produce enduring changes in behavioral responses to corticotropin-releasing factor (CRF) in rat models of anxiety. Behav Brain Res. 188, 195-200.

Tang, X. and Sanford, L.D. (2005). Home cage activity and activity-based measures of anxiety in 129P3/J, 129X1/SvJ and C57BL/6J mice. Physiol. Behav. 84, 105115.

Tang-Christensen, M., Vrang, N., Ortmann, S., Bidlingmaier, M., Horvath, T.L., and Tschöp, M. (2004). Central administration of ghrelin and agouti-related protein (83-132) increases food intake and decreases spontaneous locomotor activity in rats. Endocrinology 145, 4645-4652.

Tata, D.A., Marciano, V.A., and Anderson, B.J. (2006). Synapse loss from chronically elevated glucocorticoids: relationship to neuropil volume and cell number in hippocampal area CA3. J. Comp. Neurol. 498, 363-374.

Telegdy, G. and Adamik, A. (2013). Involvement of transmitters in the anxiolytic action of urocortin 3 in mice. Behav. Brain Res. 252, 88-91.

Tenk, C.M., Kavaliers, M., and Ossenkopp, K.P. (2006). The effects of acute corticosterone on lithium chloride-induced conditioned place aversion and locomotor activity in rats. Life Sci. 79, 1069-1080.

Tezval, H., Jahn, O., Todorovic, C., Sasse, A., Eckart, K., and Spiess, J. (2004). Cortagine, a specific agonist of corticotropin-releasing factor receptor subtype 1 , 
is anxiogenic and antidepressive in the mouse model. Proc. Natl Acad. Sci. U.S.A. $101,9468-9473$.

Thoeringer, C.K., Sillaber, I., Roedel, A., Erhardt, A., Mueller, M.B., Ohl, F., Holsboer, F., and Keck, M.E. (2007). The temporal dynamics of intrahippocampal corticosterone in response to stress-related stimuli with different emotional and physical load: an in vivo microdialysis study in C57BL/6 and DBA/2 inbred mice. Psychoneuroendocrinology 32, 746-757.

Timpl, P., Spanagel, R., Sillaber, I., Kresse, A., Reul, J.M., Stalla, G.K., Blanquet, V., Steckler, T., Holsboer, F., and Wurst, W. (1998). Impaired stress response and reduced anxiety in mice lacking a functional corticotropin-releasing hormone receptor 1. Nat. Genet. 19, 162-166.

Tovote, P., Fadok, J.P., and Lüthi, A. (2015). Neuronal circuits for fear and anxiety. Nat. Rev. Neurosci. 16, 317-331.

Tran, L., Schulkin, J., and Greenwood-Van Meerveld, B. (2014). Importance of CRF receptor-mediated mechanisms of the bed nucleus of the stria terminalis in the processing of anxiety and pain. Neuropsychopharmacology 39, 2633-2645.

Tsang, H.W. and Ho, T.Y. (2010). A systematic review on the anxiolytic effects of aromatherapy on rodents under experimentally induced anxiety models. Rev. Neurosci. 21, 141-152.

Tsukiyama, N., Saida, Y., Kakuda, M., Shintani, N., Hayata, A., Morita, Y., Tanida, M., Tajiri, M., Hazama, K., Ogata, K., Hashimoto, H., and Baba, A. (2011). PACAP centrally mediates emotional stress-induced corticosterone responses in mice. Stress $14,368-375$. 
Valdez, G.R., Zorrilla, E.P., Rivier, J., Vale, W.W., and Koob, G.F. (2003). Locomotor suppressive and anxiolytic-like effects of urocortin 3, a highly selective type 2 corticotropin-releasing factor agonist. Brain Res. 980, 206-212.

Valdez, G.R., Inoue, K., Koob, G.F., Rivier, J., Vale, W.W., and Zorrilla, E.P. (2002). Human urocortin 2: mild locomotor suppressive and delayed anxiolytic-like effects of a novel corticotropin-releasing factor related peptide, Brain Res. 943, $142-150$

Vale, W., Spiess, J,, Rivier, C., and Rivier, J. (1981). Characterization of a 41-residue ovinehypothalamic peptide that stimulates secretion of corticotropin and betaendorphin. Science 213, 1394-1397.

Valentino, R.J., Chen, S., Zhu, Y., and Aston-Jones, G. (1996). Evidence for divergent projections to the brain noradrenergic system and the spinal parasympathetic system from Barrington's nucleus. Brain Res. 732, 1-15.

van Gaalen, M.M., Stenzel-Poore, M.P., Holsboer, F., and Steckler, T. (2002). Effects of transgenic overproduction of $\mathrm{CRH}$ on anxiety-like behaviour. Eur. J. Neurosci. 15, 2007-2015.

Van Pett, K., Viau, V., Bittencourt, J.C., Chan, R.K., Li, H.Y., Arias, C., Prins, G.S., Perrin, M., Vale, W., and Sawchenko, P.E. (2000). Distribution of mRNAs encoding CRF receptors in brain and pituitary of rat and mouse. J. Comp. Neurol. 428, 191-212.

Vaudry, D., Falluel-Morel, A., Bourgault, S., Basille, M., Burel, D., Wurtz, O., Fournier, A., Chow, B., Hashimoto, H., Galas, L., and Vaudry, H. (2009). Pituitary adenylate cyclase-activating polypeptide and its receptors: 20 years after the discovery. Pharmacol. Rev. 61, 283-357. 
Vaughan, J., Donaldson, C., Bittencourt, J., Perrin, M.H., Lewis, K., Sutton, S., Chan, R., Turnbull, A.V., Lovejoy, D., Rivier, C., Rivier, J., Sawchenko, P.E., and Vale, W. (1995). Urocortin, a mammalian neuropeptide related to fish urotensin I and to corticotropin-releasing factor. Nature 378, 287-292.

Veldhuis, H.D. and De Wied, D. (1984). Differential behavioral actions of corticotropin-releasing factor (CRF). Pharmacol. Biochem. Behav. 21, 707-713.

Venihaki, M., Sakihara, S., Subramanian, S., Dikkes, P., Weninger, S.C., Liapakis, G., Graf, T., and Majzoub, J.A. (2004). Urocortin III, a brain neuropeptide of the corticotropin-releasing hormone family: modulation by stress and attenuation of some anxiety-like behaviours. J. Neuroendocrinol. 16, 411-422.

Vermes, I., Smelik, P.G., and Mulder, A.H. (1976). Effects of hypophysectomy, adrenalectomy and corticosterone treatment on uptake and release of putative central neurotransmitters by rat hypothalamic tissue in vitro. Life Sci. 19, 17191725.

Viana, M.B., Tomaz, C., and Graeff, F.G. (1994). The elevated T-maze: a new animal model of anxiety and memory. Pharmacol. Biochem. Behav. 49, 549-554.

Vincent, M.Y. and Jacobson, L. (2014). Glucocorticoid receptor deletion from the dorsal raphé nucleus of mice reduces dysphoria-like behavior and impairs hypothalamic-pituitary-adrenocortical axis feedback inhibition. Eur. J. Neurosci. 39, 1671-1681.

Vicentini, J.E., Céspedes, I.C., Nascimento, J.O., Bittencourt, J.C., and Viana, M.B. (2014). CRF type 1 receptors of the medial amygdala modulate inhibitory avoidance responses in the elevated T-maze. Horm. Behav. 65, 195-202.

Vicentini, E., Arban, R., Angelici, O., Maraia, G., Perico, M., Mugnaini, M., Ugolini A., Large C., Domenici, E., Gerrard, P., Bortner, D., Mansuy, I.M., Mangiarini, L., 
and Merlo-Pich, E. (2009). Transient forebrain over-expression of CRF induces plasma corticosterone and mild behavioural changes in adult conditional CRF transgenic mice. Pharmacol. Biochem. Behav. 93, 17-24.

Vielkind, U., Walencewicz, A., Levine, J.M., and Bohn, M.C. (1990). Type II glucocorticoid receptors are expressed in oligodendrocytes and astrocytes. J. Neurosci. Res. 27, 360-373.

Walf, A.A. and Frye, C.A. (2007). The use of the elevated plus maze as an assay of anxiety-related behavior in rodents. Nat. Protoc. 2, 322-328.

Wall, P.M. and Messier, C. (2001). Methodological and conceptual issues in the use of the elevated plus-maze as a psychological measurement instrument of animal anxiety-like behavior. Neurosci. Biobehav. Rev. 25, 275-286.

Walsh, R.N. and Cummins, R.A. (1976). The open-field test: a critical review. Psychol. Bull. 83, 482-504.

Wang, H., Xing, X., Liang, J., Bai, Y., Lui, Z., and Zheng, X. (2014). High-dose corticosterone after fear conditioning selectively suppresses fear renewal by reducing anxiety-like response. Pharmacol. Biochem. Behav. 124, 188-195.

Ward, H.E., Johnson, E.A., Goodman, I.J., Birkle, D.L., Cottrell, D.J., and Azzaro, A.J. (1998). Corticotropin-releasing factor and defensive withdrawal: inhibition of monoamine oxidase prevents habituation to chronic stress. Pharmacol. Biochem. Behav. 60, 209-215.

Warembourg, M. (1975). Radioautographic study of the rat brain and pituitary after injection of 3H dexamethasone. Cell Tissue Res. 161, 183-191.

Waters, P. and McCormick, C.M. (2011). Caveats of chronic exogenous corticosterone treatments in adolescent rats and effects on anxiety-like and 
depressive behavior and hypothalamic-pituitary-adrenal (HPA) axis function. Biol. Mood Anxiety Disord. 1(1), 4.

Weaver, S.A., Aherne, F.X., Meaney, M.J., Schaefer, A.L., and Dixon, W.T. (2000). Neonatal handling permanently alters hypothalamic-pituitary- adrenal axis function, behaviour, and body weight in boars. J. Endocrinol. 164, 349-359.

Weiser, M.J., Foradori, C.D., and Handa, R.J. (2010). Estrogen receptor beta activation prevents glucocorticoid receptor-dependent effects of the central nucleus of the amygdala on behavior and neuroendocrine function. Brain Res. 1336, 78-88.

Welberg, L.A., Seckl, J.R., and Holmes, M.C. (2001). Prenatal glucocorticoid programming of brain corticosteroid receptors and corticotrophin-releasing hormone: possible implications for behaviour. Neuroscience 104, 71-79.

Weninger, S.C., Dunn, A.J., Muglia, L.J., Dikkes, P., Miczek, K.A., Swiergiel, A.H., Berridge, C.W., and Majzoub, J.A. (1999). Stress-induced behaviors require the corticotropin-releasing hormone $(\mathrm{CRH})$ receptor, but not $\mathrm{CRH}$. Proc. Natl Acad. Sci. U.S.A. 96, 8283-8288.

Wilcoxon, J.S. and Redei, E.E. (2007). Maternal glucocorticoid deficit affects hypothalamic-pituitary-adrenal function and behavior of rat offspring. Horm. Behav. 51, 321-327.

Witter, M.P. and Amaral, D.G. (2004). Hippocampal formation. In: G. Paxinos, ed. The rat nervous system, 3rd ed. (Amsterdam: Elsevier), pp. 635-704.

Yang, X.-M. and Dunn, A.J. (1990). Central beta1-adrenergic receptors are involved in CRF-induced defensive withdrawal, Pharmacol. Biochem. Behav. 36, 847851. 
Yang, X.M., Gorman, A.L., and Dunn, A.J. (1990). The involvement of central noradrenergic systems and corticotropin-releasing factor in defensivewithdrawal behavior in rats. J. Pharmacol. Exp. Ther. 255, 1064-1070.

Yoon, S.H., Kim, B.H., Ye, S.K., and Kim, M.H. (2014). Chronic non-social stress affects depressive behaviors but not anxiety in mice. Korean J. Physiol. Pharmacol. 18, 263-268.

Zaletel, I, Filipović, D, and Puškaš, N. (2016). Chronic stress, hippocampus and parvalbumin-positive interneurons: what do we know so far? Rev. Neurosci. 27, 397-409.

Zangrossi, H. Jr and Graeff, F.G. (2014). Serotonin in anxiety and panic: contributions of the elevated T-maze. Neurosci. Biobehav. Rev. 46, 397-406.

Zenker, N. and Bernstein, D.E. (1958). The estimation of small amounts of corticosterone in rat plasma. J. Biol. Chem. 231, 695-701.

Zieba, B., Grzegorzewska, M., Branski, P., Domin, H., Wieronska, J.M., Hess, G., and Smialowska, M. (2008). The behavioural and electrophysiological effects of CRF in rat frontal cortex. Neuropeptides 42, 513-523.

Zorrilla, E.P., Roberts, A.J., Rivier, J.E., and Koob, G.F. (2013). Anxiolytic-like effects of antisauvagine-30 in mice are not mediated by CRF2 receptors. PLoS One 8(8), e63942.

Zorrilla, E.P., Valdez, G.R., Nozulak, J., Koob, G.F., and Markou, A. (2002). Effects of antalarmin, a CRF type 1 receptor antagonist, on anxiety-like behavior and motor activation in the rat. Brain Res. 952, 188-199. 
Figure legend

Figure 1 Synoptic diagram illustrating the principal brain regions involved in stressrelated neurocircuits and behaviors. The limbic prefrontal cortex includes the orbital gyrus in its ventral part and the infralimbic, prelimbic, and cingulate gyri in its medial part In the amygdaloid nuclear complex, the stress-sensitive nuclei are the basolateral $(B L A)$, mainly projecting to the medial $(M e A)$ and central $(\mathrm{CeA})$ ones considered both as efferent structures to hypothalamic and brainstem structures. The inhibitory influence of the hippocampus to the HPA axis is mediated by neurons from the ventral subiculum or via the lateral septum (LS). The nucleus accumbens belongs to the limbic striatum; its efferent region constitutes the ventral part of the globus pallidus (GP). All these forebrain regions are together highly reciprocally interconnected (dotted arrows) as well as with brainstem regions: they receive monoaminergic inputs from the nuclei of the raphe, the locus coeruleus, and the ventral tegmental area (VTA) and also signals from the autonomic solitary (NST) and parabrachial nuclei as well as from the periaqueductal gray (PAG). They can modulate corticotropin releasing hormone $(\mathrm{CRH})$ secretion by indirect pathways (fine continous arrows) via the bed nucleus of the stria terminalis (BNST) and hypothalamic nuclei such as the dorsomedial (DM) and preoptic area (POA). Autonomic regions from the brainstem as well as the hypothalamic nuclei and BNST display direct inputs (thick continous arrows) to the paraventricular nucleus of the hypothalamus (PVN) which represents the final integrator of the stress response in the brain, activating the endocrine hypothalamic-pituitary-adrenal (HPA) axis for glucocorticoid secretion from the adrenal cortex. Glucocorticoids regulate their own release via feedback loops on the hormonal axis and throughout forebrain limbic 
regions known to influence the stress response (structures in grey boxes). ACTH: adrenocorticotropin hormone. 